\title{
Water resource management in the context of a non-potable water reuse case study in arid climate
}

\author{
G. Seguela ${ }^{1}$ (D) J. R. Littlewood ${ }^{1} \cdot$ G. Karani $^{2}$ \\ ${ }^{1}$ Sustainable and Resilient Built Environment Group, Cardiff School of Art and Design, Cardiff Metropolitan University, Western Avenue, \\ Cardiff, UK \\ ${ }^{2}$ Environment and Public Health Research Group, Cardiff School of Health Sciences, Western Avenue, Cardiff, UK
}

Received: 30 June 2019/Revised: 16 May 2020/ Accepted: 18 May 2020/Published online: 1 June 2020

(C) The Author(s) 2020

\begin{abstract}
This study evaluates an existing non-potable water system serving outdoor services for a medical facility case study (MFCS) in Abu Dhabi (AD), United Arab Emirates, using mixed methods research to identify water demand and availability of non-potable water, and to optimize water reuse for reducing waste, energy consumption and greenhouse gas emissions (GHG). The MFCS footprint includes $50 \%$ landscaping. The water used for irrigation is from non-clinical/non-potable water, treated condensate water, a by-product of air conditioning. For 5 months per year, there is a predicted non-potable water deficit, so costly and non-sustainable desalinated potable water is required for irrigation. The findings include that there is a nonpotable water deficit due to an excessive consumption for landscape irrigation (LI) and water features (WF), and that $177,288 \mathrm{~m}^{3}$ of condensate and desalinated water was wasted (equivalent to 71 Olympic swimming pools). The contribution of this research is to demonstrate that water wastage, a contributor to GHG emissions, is due to inadequate field testing and verification, water tank storage problems and a lack of LI and WF water demand management. Strategies to address these issues are suggested and will be useful to building owners, operations and maintenance teams and facility managers to substantially decrease water consumption in any type of buildings with a non-potable water system, as well as helping AD to achieve its target of a $22 \%$ reduction in GHG emissions by 2030 (Environment AgencyAbu Dhabi (EAD 2017)).
\end{abstract}

Keywords Water resource - Water security · Nonpotable water reuse $\cdot$ Retro-commissioning - Water supply

G. Seguela

seguelag@gmail.com; geseguela@cardiffmet.ac.uk and demand · Energy and carbon reductions - Landscape irrigation - Water features

\section{Introduction}

\subsection{Background}

Middle East countries are among the lowest-ranked globally for availability of renewable freshwater per capita (World Bank 2012). In 2018, 13 Arab countries were among the world's 19 most water-scarce countries (Pizzi 2010; Mitchell 2009) and per capita water availability is below 200 cubic meters $\left(\mathrm{m}^{3}\right)$ per year in eight Middle East countries, including the United Arab Emirates (UAE). (World Bank 2012). The UAE has only a two-day desalinated water storage capacity, making the country vulnerable to any disruption in its desalination plants (Shahid et al. 2013).

Abu Dhabi (AD), the capital of the UAE, is the largest of the seven emirates that make up the UAE, occupying more than 80 per cent $(\%)$ of the country's total area (Veerapaneni et al. 2007). 100\% of potable water in AD is used for commercial, residential and industry buildings, including outdoor landscape irrigation (LI) (Environment Agency Abu Dhabi (EAD) 2014).

The medical facility case study (MFCS) for this research is built on a 23 acres man-made island and has 364 beds (expandable to 490 in-patient beds) over 20 floors above ground, including five medical institutes in addition to $14,000 \mathrm{~m}^{2}$ of gallery area and $1500 \mathrm{~m}^{2}$ of retail space, with $24,000 \mathrm{~m}^{2}$ landscaping representing $50 \%$ of the facility footprint. One of the current methods of avoiding using potable (i.e., desalinated) water for LI and water features 
(WF) is utilizing air conditioning (A/C)-treated condensate water, a product of air handling unit (AHU) air conditioning (Seguela et al. 2017a, b, c). However, due to peak condensate formation occurring in summer (MaySeptember), there is a shortfall of condensate water availability in winter (December-February).

In 2017, this shortfall was reduced by the authors' implementing a series of interventions using an action research methodology (Magoon et al. 2010) in case study one (CS1 Water Resource), as detailed in Sect. 2.1. As a result, the MFCS energy monitoring and control system (EMCS) recorded $66 \%$ average non-potable water use for both LI and WF.

\subsection{Healthcare context for water conservation}

To the authors' knowledge, there has been no published literature on water research or energy research related to the healthcare sector since April 2008. As such, this paper addresses a gap in knowledge regarding non-potable water standards for LI and WF in the healthcare context. While this case study was located in the UAE, the findings are relevant to healthcare facilities in similar climates. In the USA, in 2002, water consumption ranged from 260 to 1128 $\mathrm{m}^{3}$ per year per patient bed for hospitals in the 133-510 bed range (Healthcare Environmental Resource Center (HERC) 2015), which represents 0.71 to $2.21 \mathrm{~m}^{3}$ per day per bed, respectively. Yet hospitals' water use varies widely depending on type, size, geographical location and water use equipment and practices (Seguela et al. 2020). The MFCS records indicated $2.97 \mathrm{~m}^{3}$ water consumption per patient bed per day (see Fig. 1) in $2016\left(395,916 \mathrm{~m}^{3} \div\right.$ 364 beds $\div 366$ days) which means water use for LI alone in 2016 represented a substantial quantity (36\%) of the total water demand (ibid.). Thus, a significant opportunity exists to conserve water for outdoor use, while at the same time reusing non-potable water for LI and WF to achieve zero-potable water outdoor use. (Seguela et al. 2020, p. 2).

\subsection{Gaps Analysis Leading to Change in Practice}

As identified in Table 1, the professional engineering standards and codes in $\mathrm{AD}$ either conflict with or ignore one another. While $\mathrm{A} / \mathrm{C}$ condensate water reuse is mentioned in the Urban Planning Council (UPC 2010b) Design Public Realm, the Pearl Building Rating System (UPC 2010a) makes it optional because it assumes projects will use treated sewage effluent (TSE) to reduce potable water use. The Department of Municipal Affairs and Transport (DMAT 2013) encourages the reuse of condensate water, a strategy not reflected in the Estidama program (UPC 2010a) nor in any other standard. DMAT (2013) Plumbing Systems, Chapter 29, refers to the AD Uniform Plumbing Code (EAD 2009), Health Authority Abu Dhabi (HAAD 2012) and the American Society of Heating, Refrigerating and Air-Conditioning Engineers (ASHRAE 2000) standards and guidelines. DMAT also refers to the UPC (2010b) Public Realm Design Manual for water conservation in landscaping and, more particularly, to water recycling as TSE reuse. Thus, the only common ground of DMAT, RSB, HAAD and EAD is the regulation of Legionella for potable water and wastewater and the reuse of TSE. Moreover, HAAD released an updated standard in early 2012 on the use of wastewater in $\mathrm{AD}$, which prohibits treated or untreated wastewater reuse (HAAD 2011). While the MFCS was authorized by HAAD and RSB (2010) to reuse $\mathrm{AHU} \mathrm{A} / \mathrm{C}$ condensate water, the TSE connection to Maryah Island (the MFCS location) in 2017 is unknown (Jarrar 2017).
Fig. 1 MFCS total building water use against LI consumption based on 2016 Abu Dhabi Distribution Company (2017) Water Bills (Seguela et al. 2020, p. 3)
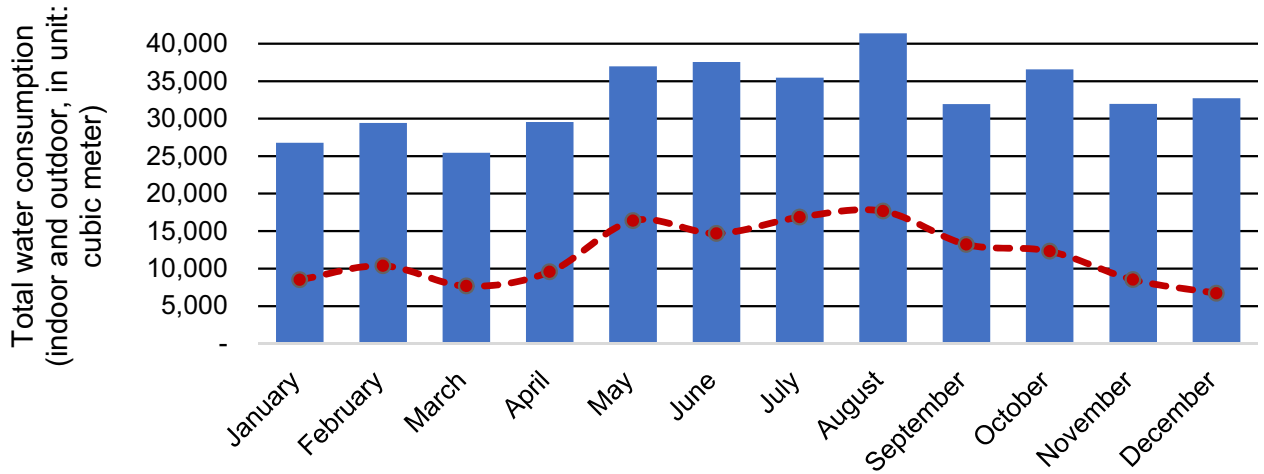

Months of the year 
Table 1 AD Standards and Policies gap analysis related to water conservation

\begin{tabular}{|c|c|c|}
\hline $\begin{array}{l}\text { Existing codes, standards and } \\
\text { strategies }\end{array}$ & Local water conservation regulation gaps & References \\
\hline Water standard & $\begin{array}{l}\text { This standard does not address non-potable water reuse, but only prohibits } \\
\text { the reuse of wastewater. Yet the HAAD authorized the reuse of treated } \\
\text { condensate water for LI and WF use at the MFCS }\end{array}$ & $\begin{array}{l}\text { Health Authority Abu Dhabi } \\
\text { (HAAD 2011, 2012) }\end{array}$ \\
\hline $\begin{array}{l}\text { Pearl building rating system } \\
\text { guideline }\end{array}$ & $\begin{array}{l}\text { Water-saving strategies implementation are elective, not mandatory. UPC } \\
\text { does not address onsite non-potable water reuse but treated sewage } \\
\text { effluent (TSE) only }\end{array}$ & $\begin{array}{l}\text { Urban Planning Council (UPC } \\
\text { 2010a) }\end{array}$ \\
\hline $\begin{array}{l}\text { International building Code } \\
\text { 2013, Chapter } 29 \text { plumbing } \\
\text { systems }\end{array}$ & $\begin{array}{l}\text { Non-potable water reuse is addressed in terms of Legionella prevention. } \\
\text { Building hydraulics, such as but not limited to water storage or flow } \\
\text { meters, for non-potable water systems is not addressed }\end{array}$ & $\begin{array}{l}\text { Department of Municipal } \\
\text { Affairs and Transport (DMAT } \\
\text { 2013) }\end{array}$ \\
\hline $\begin{array}{l}\text { Uniform Plumbing Code of AD } \\
\text { Emirate }\end{array}$ & $\begin{array}{l}\text { Graywater storage is authorized for } 72 \mathrm{~h} \text { maximum. Condensate water } \\
\text { storage is not fully addressed, but essentially rainwater. Building } \\
\text { hydraulics, such as but not limited to water storage or flow meters, for } \\
\text { non-potable water systems is not addressed }\end{array}$ & $\begin{array}{l}\text { Environment Agency- Abu } \\
\text { Dhabi (EAD 2009) }\end{array}$ \\
\hline
\end{tabular}

\subsection{Contribution to changes in practice}

The intervention described in this paper (deriving from the first author's doctoral research) proposes a water conservation and reuse strategy as the basis for a potable water reduction protocol (WRP) to fill the gaps identified in Table 1, addressing:

- development and application of an onsite outdoor water demand strategy to reduce water consumption by testing soil water-holding capacity onsite (Seguela et al. 2017a; Seguela 2018), and

- reduction in water wastage by building hydraulics field testing and verification (water storage tanks; water tanks connection; water tanks gauge; and flow meters) and energy and controls system adequate specification (valves and pumps; sensors; and water and energy data integration to building controls) serving the outdoor water system post-opening through retrocommissioning.

\section{Materials and methods}

\subsection{Case study one (CS1): water resources}

CS1 uses a quantitative data collection process (Creswell and Plano Clark 2011) and includes two pilot empirical studies (Yin 2014), one pilot calculation, two interventions and three calculations. This paper will address the following studies and calculation as detailed below and represented in Fig. 2.

- Pilot Empirical Study One (PP1) (2016 Water Balance and Building Water System Hydraulic Review):
CASE STUDY ONE (CS1): WATER RESOURCES

Water Balance

Pilot Empirical Study One (PP1 2016) (Seguela et al

2017c and Section 2.3 below):

- 2016 Water Balance; and

- Hydraulic Review based on:

- Energy monitoring \& control system (EMCS) records;

- 2014 theoretical model [January 2016-December 2016

(12 months)]

CS1 Intervention One:

- 2017 Water Balance [EMCS records February 2017January 2018 (12 months)] in Section 3.1 below; and

- 2017 Non-Potable Water System Enhancement (July 2017- April 2018) in Section 3.2 below

CS1 Calculation Three (Calc3):

- Water Features Demand Calculation (Equation One to Four) in Seguela et al 2017c and Section 2.5 below.

Fig. 2 Proposed research strategy summary

commencing in 2016, this study starts the Water Balance (supply/demand) analysis based on 12 months theoretical A/C condensate water supply and WF demand (Cardno 2014), and Abu Dhabi Municipality (ADM) (2013) irrigation rate LI demand from January 2016 to December 2016. The analysis includes a water system hydraulic review (June 2016).

- Intervention One (2017 Water Balance and NonPotable Water System Enhancement): this continues the Water Balance analysis based on 12 months of EMCS water records (February 2017-January 2018) for comparison with CS1 and PP1 results to assess existing non-potable water supply, establish water consumption and identify outdoor water demand and non- 
potable water availability. This intervention includes the enhancement of the existing non-potable water system as the results of the hydraulic review (CS1, PP1) initiated by the author in June 2016 (2016 Water Balance and Hydraulic Review).

- Calculation Three (Calc3): WF: Water Demand Calculations to establish water supply demand and nonpotable water supply deficit or excess.

\subsection{CS1 pilot empirical study one (PP1): 2016 water balance methodology}

The MFCS design includes a treated non-potable water system comprising 167 AHUs and 40 fan coil units (FCUs). The condensate water produced by the system serves the water demand of the $36,257 \mathrm{~m}^{2}$ outdoor LI and small to large WF, totalling $3289 \mathrm{~m}^{2}$.

The study involves a comparison of an on-site system to the use of municipal desalinated potable water in terms of environmental impact, energy consumption, operation maintenance, GHG emissions and cost savings. Part of this analysis is the development of a water balance, which in 2016 comprised four elements as illustrated in Fig. 3a-d. The water data are collected and analyzed via subflow meters three, four and six (M3, M4 and M6 in Fig. 3). The data are captured daily via the EMCS.

By reusing the onsite $\mathrm{A} / \mathrm{C}$ condensate water throughout the year, the MFCS aimed to save $124,100 \mathrm{~m}^{3}$ in 2016 equivalent to 50 Olympic swimming pools (Federation International de Natation (FINA) 2018) —of desalinated potable water and subsequently avoid 1873.91 tonnes of carbon dioxide equivalent emissions $\left(\mathrm{tCO}_{2 \mathrm{e}}\right)$. This estimation was based on the EAD (2012) emissions factor $\left(124,100 \mathrm{~m}^{3} \times 0.0151 \mathrm{tCo}_{2 \mathrm{e}}\right)$ excluding the electrical consumption of the onsite non-potable water treatment system. The water saving was based on the capacity of the existing AHU A/C condensate water to supply a theoretical $442 \mathrm{~m}^{3}$ of water average per day, based on psychrometric properties of the air and the weather pattern of AD (International Water Management Institute (IWMI) 2018) to satisfy an irrigation demand based on the ADM irrigation rate standard of $312 \mathrm{~m}^{3}$ per day and $28 \mathrm{~m}^{3}$ per day for WF
Fig. 32016 Water balance methodology. Adapted from Seguela et al. 2017a, p. 554

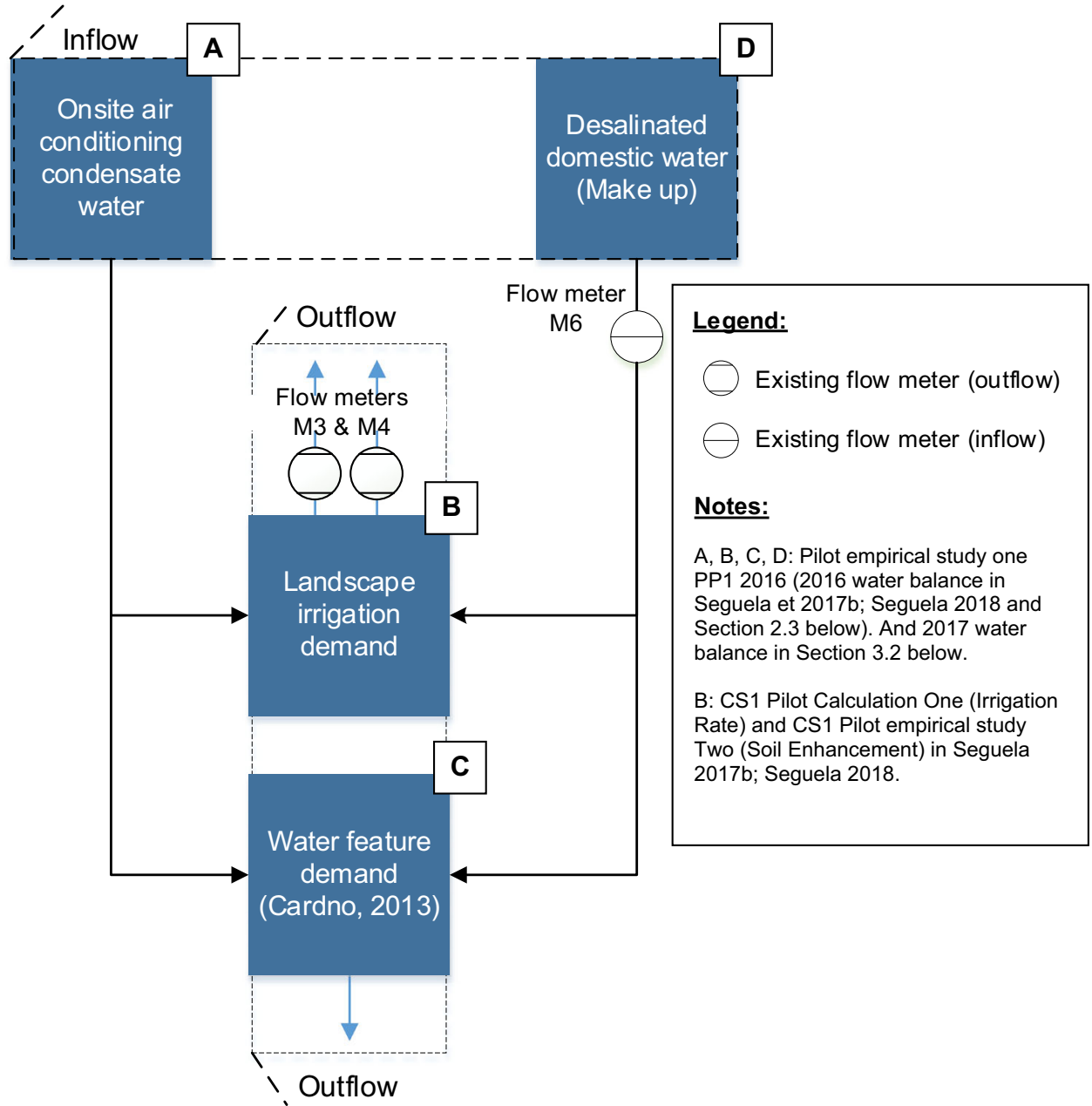


$\left(312 \mathrm{~m}^{3}+28 \mathrm{~m}^{3} \times 365\right.$ days $\left.=124,100 \mathrm{~m}^{3}\right)(\mathrm{ADM}$ 2013).

Based on the theoretical model (Cardno 2014), it was established that the condensate water could not provide $100 \%$ of LI and WF demand year around, because only a very small quantity of condensate water would be generated by the HVAC system during reduced usage the winter and spring months (67 and $229 \mathrm{~m}^{3}$ per day, respectively). As shown in Table 2, for 5 months of the year, there would be an $\mathrm{A} / \mathrm{C}$ condensate water deficit of $19,235 \mathrm{~m}^{3}$ and desalinated water would be needed to meet this deficit.

\subsection{Pilot project results reflection}

\subsubsection{CS1 PP1 summary results: 2016 water balance}

Figure 4 builds on Seguela et al. (2017a, b). This water analysis includes both the results of the simplified modeling of the condensation from the existing $\mathrm{A} / \mathrm{C}$ systems (theoretical model by Cardno 2014) of the MFCS and the water metered demand in 2016 for LI. The percentage per month indicates the quantities of condensate water used for LI in 2016, against the total water demand for LI. In 2016, the condensate water deficit ranged from 6\% in March to $85 \%$ in January, with an average condensate water deficit of $47.5 \%$ over 6 months based on the theoretical model (Cardno 2014). This model, as per Fig. 3 (Water Balance Methodology), was verified in 2017 by measuring water demand and water supplied by flow meters installed in January 2017.

\subsection{Intervention and calculation methodology}

\subsubsection{Water consumption monitoring}

In January 2017, the project installed new clamp-on ultrasonic flow meters (the performance measurement for the flow meters was not provided by the operations and maintenance (O\&M) team) at the exits of the condensate water tanks and the WF tank and at the desalinated domestic water line to account for condensate water generation and WF desalinated water consumption in addition to LI desalinated water consumption (Fig. 5, flow meters M1, M2, M5, M7). Water consumption was recorded through the EMCS, which records hourly water consumption via flow meters (M1 to M7) from 12 am to $12 \mathrm{pm}$ daily. The consumption analysis of both condensate and desalinated makeup water was undertaken by water flow meter recording as described in the legend of Fig. 5 and as follows.

- The total raw condensate water supply recorded in $\mathrm{m}^{3}$ was calculated by adding the water data from flow meter M1 and flow meter M2 and reported monthly.

- The total LI consumption recorded in $\mathrm{m}^{3}$ was calculated by adding the water data from flow meter M3 and flow meter M4 and reported monthly.

- The LI desalinated makeup water consumption was recorded in $\mathrm{m}^{3}$ from flow meter M5 and reported monthly.

- The WF desalinated makeup water consumption was recorded in $\mathrm{m}^{3}$ from flow meter M6 and reported monthly.

- The total WF water consumption was recorded in $\mathrm{m}^{3}$ from flow meter M7 and reported monthly.

- The WF condensate water consumption was calculated in $\mathrm{m}^{3}$ and computed by deducting the total WF water consumption recorded at flow meter $\mathrm{M} 7$ to the WF makeup water consumption recorded at flow meter M6 and reported monthly.

- The LI condensate water consumption calculated in $\mathrm{m}^{3}$ was computed by adding the water data from flow meter M3 and flow meter M4 and deducted from the LI makeup water consumption recorded at flow meter M5 and reported monthly.

\subsubsection{Non-potable water system enhancement}

The hydraulics review revealed that the non-potable water system needed enhancement as routine inspection revealed that the ozone/chlorine treatment system serving the WF was not operational and that the three-way valve (see

Table 2 Estimated water deficit based on ADM (2013) irrigation rate standard and condensate water theoretical model (Cardno 2014)

\begin{tabular}{|c|c|c|c|c|c|}
\hline Non-potable water supply versus outdoor water demand in $\mathrm{m}^{3}$ & $\begin{array}{l}\text { December } \\
\text { Winter }\end{array}$ & January & February & $\begin{array}{l}\text { March } \\
\text { Spring }\end{array}$ & April \\
\hline 2016 theoretical condensate water supply $\left(\mathrm{m}^{3}\right)$ (Cardno 2014) & 3067 & 1270 & 1678 & 7121 & 6872 \\
\hline 2016 WF demand $\left(\mathrm{m}^{3}\right)$ estimate (Cardno 2014) & 849 & 877 & 792 & 877 & 849 \\
\hline 2016 LI demand estimate based on ADM (2013) & 5983 & 5983 & 5404 & 8959 & 8670 \\
\hline 2016 Water balance $\left(\mathrm{m}^{3}\right)$ & -3765 & -5590 & -4518 & -2715 & -2647 \\
\hline Total estimated deficit $(\%)$ & 76 & 137 & 114 & 32 & 32 \\
\hline
\end{tabular}




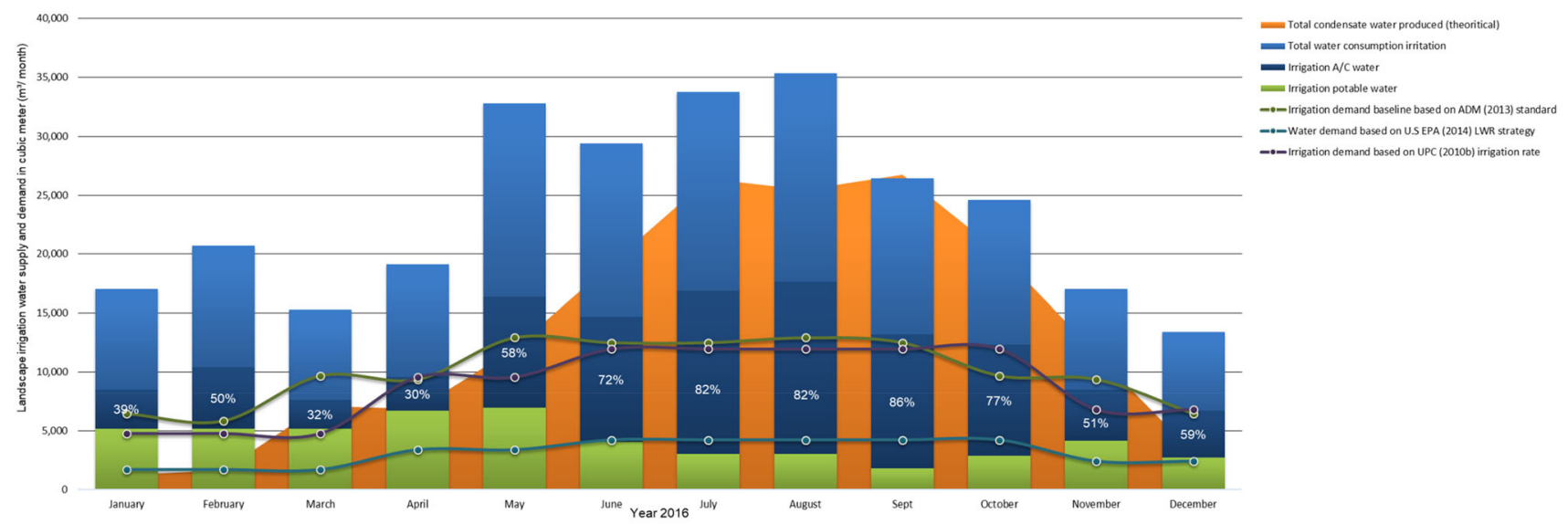

Note: The percentage provided is the percentage of condensate water used against desalinated water used. The graph lines illustrate the $2016 \mathrm{LI}$ water demand and the graph columns illustrate the 2016 water supply.

Fig. 4 CS1 PP1 (case study one (water resources) pilot empirical study one) water balance (Seguela et al. 2017c, p. 800). Note The percentage provided is the percentage of condensate water used against desalinated water used. The graph lines illustrate the 2016 LI water demand, and the graph columns illustrate the 2016 water supply

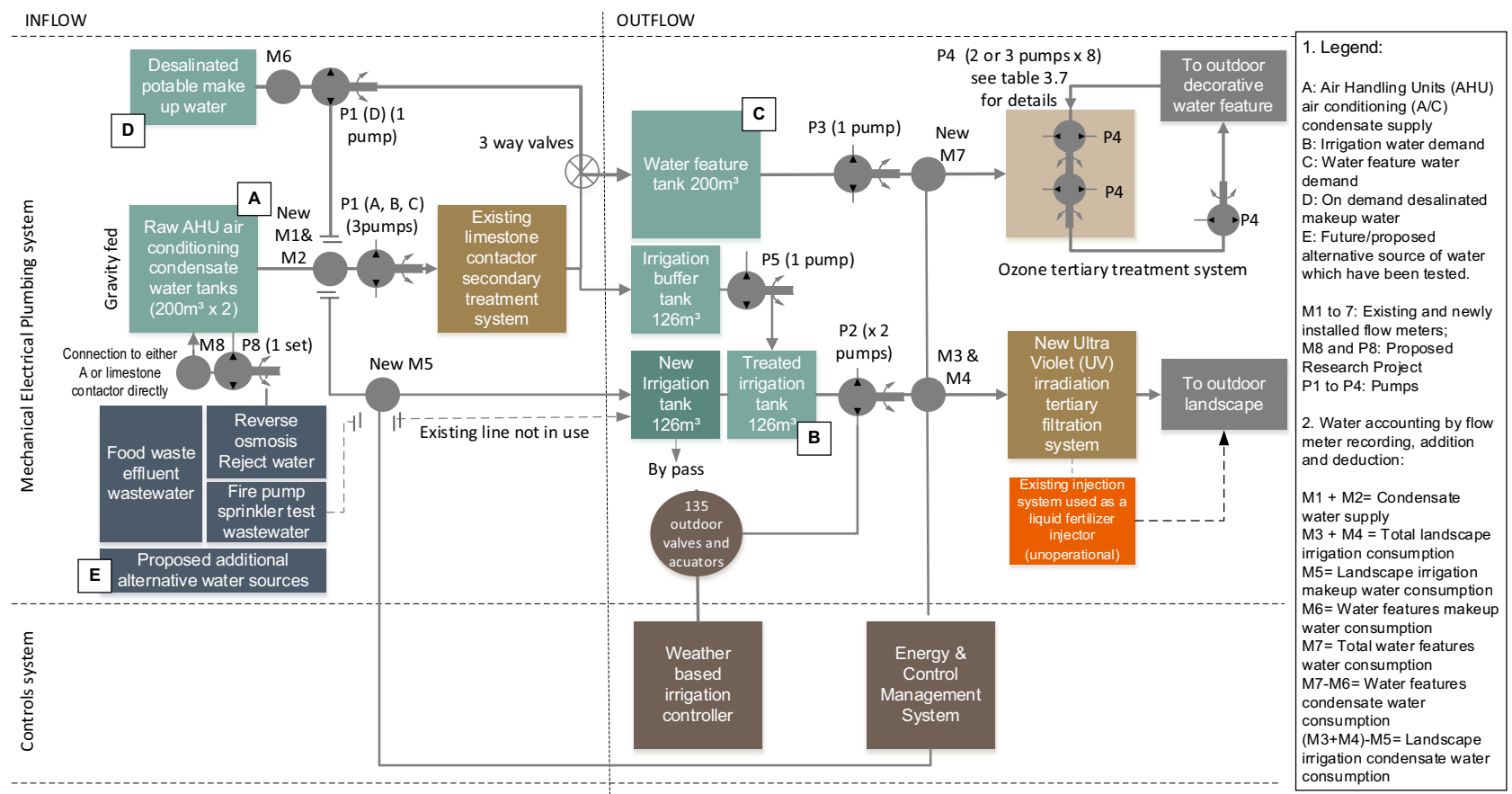

Fig. 5 Updated MFCS non-potable water system configuration diagram (Seguela et al. 2017c, p.802)

Fig. 5) serving the LI and the WF need with either condensate or desalinated water was operated manually by the O\&M team. These issues meant (a) the WF were at risk of generating biofilm, and (b) the outdoor water system relied essentially on desalinated water to meet LI and WF need. The non-potable water system enhancement initiated from the hydraulic review findings ran from July 2017 to April 2018, which is when results were analyzed (Sect. 3).

\subsection{CS1 calculation three (CS1 Calc3): WF water demand}

In 2014, average water feature (WF) demand was estimated by consultants at $28 \mathrm{~m}^{3}$ per day (Cardno 2014). This estimate excluded water evaporation and precipitation rates, backwash and maintenance. Seguela et al. (2017c) revised the calculation by computing estimated water consumption-as the input required to maintain the water level between a minimum and a maximum level adjustment- 
including atmospheric precipitation, evaporation, backwash of the filtration system and refill.

In Seguela et al. (2017c, p.803), the WF water balance is calculated with the Forrest and Williams (2010) equation (Eq. 1):

$w_{1}^{12}=\sum_{i=1} w i$

where $w_{i}$ represents water use in 1 month and $i$ is the input required to maintain the water level between minimum and a maximum level. This is after adjustment for monthly precipitation, evaporation, backflush and refill.

$Q_{\text {Precip }}$ is the water entering the WF through atmospheric precipitation, and it can be calculated using the following equation ( Gallion et al. 2014):

$Q_{\text {Precip }}=\left[A_{\text {precip }} \mathrm{WF} / t_{\text {precip }}\right] \times I_{\text {precip }}$

where $A_{\text {precip.WF }}$ represents the surface area of the WF, $I_{\text {Precip }}$ represents the average rainfall intensity, and $t_{\text {Precip }}$ represents the average precipitation time. In addition to precipitation, water is discharged from periodic backwash of the filtration system and it is represented by $Q_{\text {Back }}$ as water loss through equation three (Eq. 3) (Wheeler and Elam 2015):

$$
\begin{aligned}
Q_{\text {back }}= & \text { Backwash Rate }(l / \mathrm{min}) \\
& \times \text { Backwash Time }(\mathrm{min} / \text { cycle }) \\
& \times \text { Number of Cycles }
\end{aligned}
$$

where the backwash rate is expressed in liters per minute ( $1 /$ min), the backwash time represents the time period of backwash in minutes per cycle ( $\mathrm{min} /$ cycle), and the frequency of backwash is represented by the number of cycles per time period.

And $Q_{\text {Evap }}$ is the evaporation rate, which can be calculated using the following equation (UPC 2010b):

$$
\begin{aligned}
Q_{\text {Evap }}= & \text { Evaporation Rate }\left(0.0423 \mathrm{~m}^{3} / \mathrm{m}^{2} / \text { week }\right) \\
& \times \text { time }(\text { weeks } / \text { year }) \times \mathrm{WF} \text { surface area }\left(\mathrm{m}^{2}\right)
\end{aligned}
$$

where the evaporation rate is expressed in cubic meter $\left(\mathrm{m}^{3}\right)$ per square meter $\left(\mathrm{m}^{2}\right)$ per week by the time period of evaporation and by the surface area of the WF.

\section{Results}

\subsection{Water balance}

As noted above, in 2016, the AHU A/C condensate water deficit ranged from 6\% in March to $85 \%$ in January with an average of $47.5 \%$ based on the condensate water supply theoretical model (Cardno 2014). This model was verified in 2017 by measuring water consumption from M1, M2, M3, M5 and M7, installed and calibrated in January 2017 in addition to the existing flow meters (M4, M6) (see Fig. 5).

In 2017, the non-potable water deficit decreased but persisted for 7 months of the year (in 2017 from FebruaryMay 2017 and November 2017-January 2018). 11\% more AHU A/C condensate water $\left(179,700 \mathrm{~m}^{3}\right)$ was generated at the site in 2017 than the anticipated $161,500 \mathrm{~m}^{3}$ from the 2016 theoretical model (Cardno 2014). In addition, the summer months of the theoretical model (ibid.) anticipated $6 \%$ more condensate water supply than in 2017. However, in the winter months, the 2017 condensate water records are $61 \%$ higher than the predicted 2014 rate. The same applies to the months of spring (April-May), where the generation of condensate water is $22 \%$ more in 2017 than in 2016 .

The above water analysis does not include the WF water consumption because in 2016 there were no flow meters installed at the exit of the WF water tanks. The addition of flow meters M5 and M7 was not able to provide an accurate comparison between the 2 years (2016 and 2017) for LI.

Figure 6 offers a comparison of the total water consumption for 2016 and 2017, which includes the condensate water consumed by the LI in addition to the total desalinated water used for MFCS indoor and outdoor needs. The water used for LI alone represents $31 \%$ of total water used in 2017, against $36 \%$ in 2016. Overall MCFS consumption, excluding WF, decreased by 5\% from 2016 to 2017 (see Soil Enhancement and Valve Flow Audit Implementation and Irrigation Rate Implementation in Seguela et al. 2017b; Seguela 2018), but this reduction increased from May 2017, after the implementation and completion of CS1 PP1. 22\% more water was used in April 2017 than in April 2016, but water consumption decreased from May 2017 to reach a year-on-year reduction of $20 \%$ in December 2017, or an average saving of $16.5 \%$ for the last 8 months of 2017. These data were extracted from the 2016 and 2017 monthly water bills from Abu Dhabi Distribution Company (ADDC 2017). They exclude WF condensate water use but include the desalinated water use for WF and LI. Condensate water use for LI has been extracted from the 2016 and 2017 EMCS records (See Fig. 6).

Figure 7 provides the volume (in $\mathrm{m}^{3}$ ) of the LI consumption difference (condensate and desalinated water combined) between 2016 and 2017.

Figure 8 provides the total water used for LI alone for 2016 and 2017, which provides evidence that $18 \%$ less water was consumed in 2017 than in 2016, including the LI of an additional $6862 \mathrm{~m}^{2}$ of planting in June 2017. 


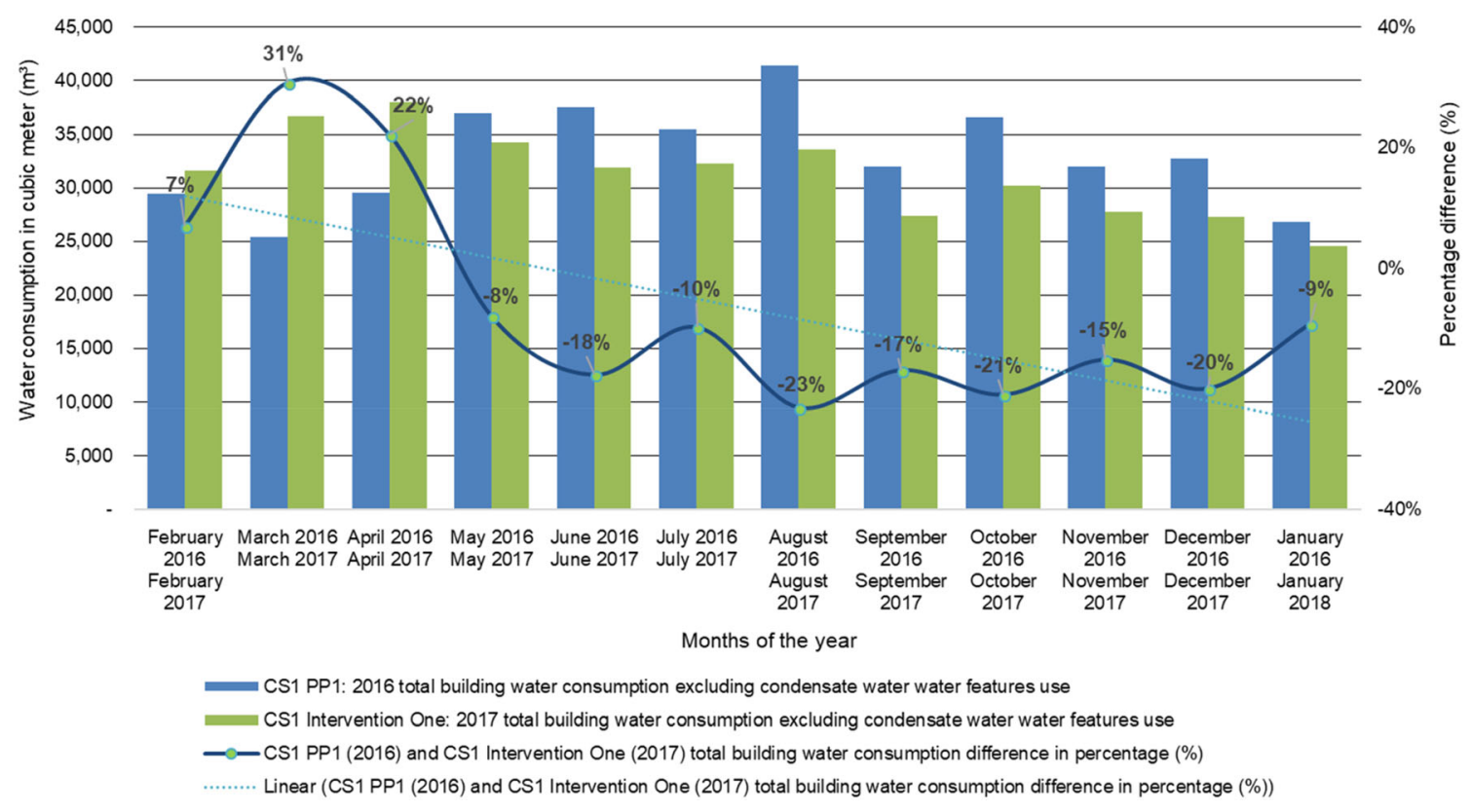

Fig. 6 CS1 Intervention One against CS1 PP1: total building water consumption

As shown in Fig. 8, in April 2017, the A/C condensate water system supplied $333 \mathrm{~m}^{3}$ per day of water, and the LI and WF used $361 \mathrm{~m}^{3}$ per day of combined potable and nonpotable water, of which $203 \mathrm{~m}^{3}$ per day came from condensate water. This means $130 \mathrm{~m}^{3}$ per day of condensate water was unused in April 2017 and municipality desalinated water was used instead, which is energy-intensive $\left(15.40 \mathrm{kWh} / \mathrm{m}^{3}\right)$ (MOEW 2010). It was also observed that $156 \mathrm{~m}^{3}$ per day desalinated water was used in April 2017 as makeup water for both the irrigation and the WF, when only $28.5 \mathrm{~m}^{3}$ was needed to supply the condensate water deficit. This scenario repeats itself for every month of the year, reaching a water wastage average of $204 \mathrm{~m}^{3}$ per day in 2017 , or $117,594 \mathrm{~m}^{3}\left(73,767 \mathrm{~m}^{3}\right.$ condensate water + $43,827 \mathrm{~m}^{3}$ desalinated makeup water) wastage over 12 months (February 2017-January 2018). In brief, 441 $\mathrm{m}^{3} /$ day of water was used in 2016 against $492 \mathrm{~m}^{3} /$ day in 2017 for the LI alone. In summer, $5667 \mathrm{~m}^{3}$ of desalinated water was supplied to the WF, even though enough recycled condensate water $\left(115,190 \mathrm{~m}^{3}\right.$ available condensate water vs $52,980 \mathrm{~m}^{3} \mathrm{LI}$ condensate water use) was available. In addition, a larger quantity of desalinated water $\left(23,463 \mathrm{~m}^{3}\right)$ was supplied for the LI in winter, spring and the beginning of summer. The reason for this is mainly a non-potable water storage challenge, which will be discussed further in Sect. 3.2.2.

However, as shown in Fig. 8, from July to December 2017 the LI used water more efficiently by consuming on average $321 \mathrm{~m}^{3}$ of condensate water per day, as opposed to $313 \mathrm{~m}^{3}$ per day average in 2016; and $37 \%$ less desalinated water was used in 2017 than in 2016 for LI alone.
Figure 8 also illustrates that the LI decreased from May 2017 after the implementation and completion of CS1 PP1 (2016 Water Balance (Seguela et al. 2017c) and Building Water System Hydraulic Review), in addition to Soil Enhancement and Valve Flow Audit Trial and Irrigation Rate Calculation (Seguela et al. 2017b; Seguela 2018).

\subsection{Non-potable water system enhancement}

\subsubsection{Summary results}

The non-potable water system enhancement initiated by the authors and executed by a third-party consultant and contractors is summarized in Table 3. As discussed in Sect. 2.3.1, in Seguela et al. (2017b) and Seguela (2018), CS1 PP1 results revealed that the non-potable water treatment system needed enhancement to ensure water quality was safe for reuse, as defined by the United States Environment Protection Agency (US EPA 2012) and distributed in efficient quantities, specifically in line with the LI controller schedule.

The works to be rectified identified in Table 3 were completed in April 2018. The water tanks' gauges and float control sensors were installed in December 2017, which in the long will help monitor and manage the water tanks' levels. In April 2018, the irrigation buffer tank (T 43-1, Fig. 9) received less water in proportion to the WF tank, and so desalinated makeup water was used instead. The cause of this problem was that the three-way valve providing the WF and the LI water tanks with either condensate water or desalinated water as needed was still 


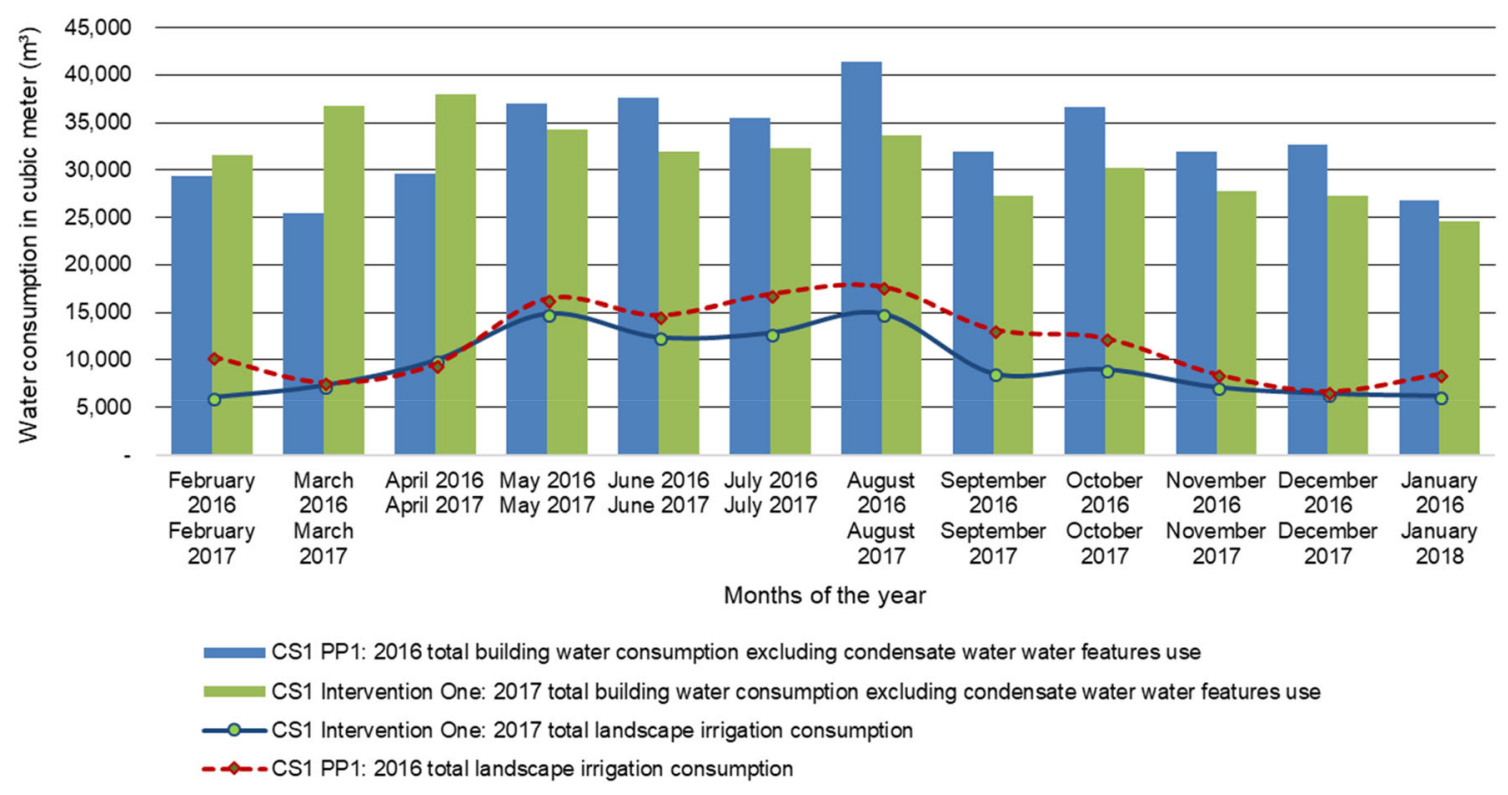

Fig. 7 CS1 Intervention One against CS1 PP1: LI consumption comparison

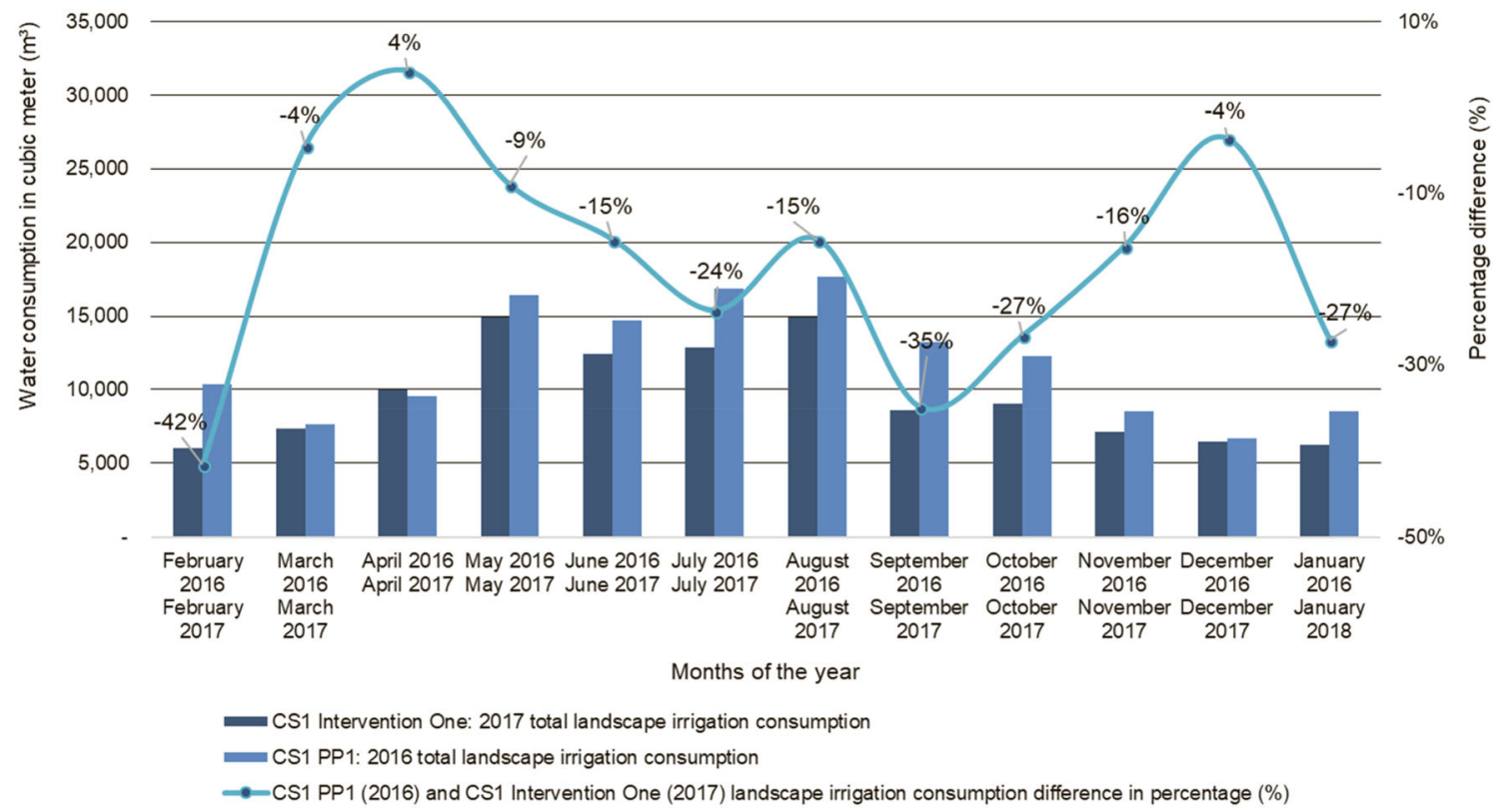

Fig. 8 CS1 Intervention One against CS1 PP1: LI consumption difference

operated manually, which may explain why excessive desalinated makeup water was used in 2017. This was confirmed by the mechanical engineer manager of the MFCS in October 2017 and by telephone conversation with the lead author in March 2018.

In reference to Fig. 9, works completed on the connection of tanks T41-1 and T42-1 prevent the condensate water overflow being drained to sewage. To the authors' knowledge, one major modification that has not been undertaken to date, and that accounts for most of the water loss, is the setting of the pressure set point for the pump serving the LI. The total volume of leakage losses occurring in a distribution system will depend on the operating pressure in the pipe distribution system (American Water Works Association (AWWA) 2016). Leakage in the distribution system is attributed in part to operational errors, such as excessive pressure and incorrect operation of pumps or closing of valves too rapidly (ibid.). That means that until these modifications are completed, and until a water leakage audit is initiated, the site will use an excessive amount of both non-potable and potable water and, consequently, waste both water and indirect energy. 
Table 3 CS1 Intervention One outcome summary (Environmental Systems Design Inc. 2016; Seguela 2018)

\begin{tabular}{|c|c|c|}
\hline Areas to be rectified & For what purpose & Consequences on the water consumption \\
\hline $\begin{array}{l}\text { Add analogue tank level gauges, where } \\
\text { required, integrated into the EMCS }\end{array}$ & $\begin{array}{l}\text { To provide additional useful operational } \\
\text { feedback on current water volume in each of } \\
\text { the six (6) tanks, and rate of fill/usage }\end{array}$ & $\begin{array}{l}\text { Monitoring non-potable water levels available } \\
\text { in tanks to meet daily demand }\end{array}$ \\
\hline $\begin{array}{l}\text { Install four new subflow meters (M1, M2, } \\
\text { M5, M7) at exit of condensate water tanks } \\
\text { and WF tank (see Fig. 5) }\end{array}$ & $\begin{array}{l}\text { To provide additional useful operational } \\
\text { feedback on current water volume usage }\end{array}$ & $\begin{array}{l}\text { Monitoring and reporting non-potable water } \\
\text { quantities and manage water demand }\end{array}$ \\
\hline $\begin{array}{l}\text { Complete integration of data from the } \\
\text { existing irrigation pumps controller(s) to } \\
\text { EMCS (see Fig. 5) }\end{array}$ & $\begin{array}{l}\text { To monitor pump speed command, measured } \\
\text { pressure, pressure set point (monitor and } \\
\text { modify), measured flow rate, pump VFD } \\
\text { fault, pump VFD run status, as well as any } \\
\text { additional parameters available for integration }\end{array}$ & $\begin{array}{l}\text { Allowing the EMCS to monitor the LI } \\
\text { controller operation and associated } \\
\text { components such as pumps pressure set point } \\
\text { to utilize water more efficiently }\end{array}$ \\
\hline $\begin{array}{l}\text { Reconfigure the three-way valve to operate } \\
\text { via a float control sensor located in the } \\
\text { WF and LI water tanks. (See Fig. 5) }\end{array}$ & $\begin{array}{l}\text { When the WF tank is on high alarm, the three- } \\
\text { way valve modulates to direct non- } \\
\text { potable water to the irrigation buffer tank and } \\
\text { WF tank automatically }\end{array}$ & $\begin{array}{l}\text { Ensuring the non-potable water is used as the } \\
\text { main water source against the makeup water } \\
\text { for both LI and WF }\end{array}$ \\
\hline $\begin{array}{l}\text { Connect the existing water tank T41-1 to } \\
\text { the irrigation tank T42-1 (See Fig. 9) }\end{array}$ & To allow both tanks to be used for irrigation & $\begin{array}{l}\text { Decreasing quantity of non-potable water to be } \\
\text { dumped to sewage when tanks overflow }\end{array}$ \\
\hline
\end{tabular}

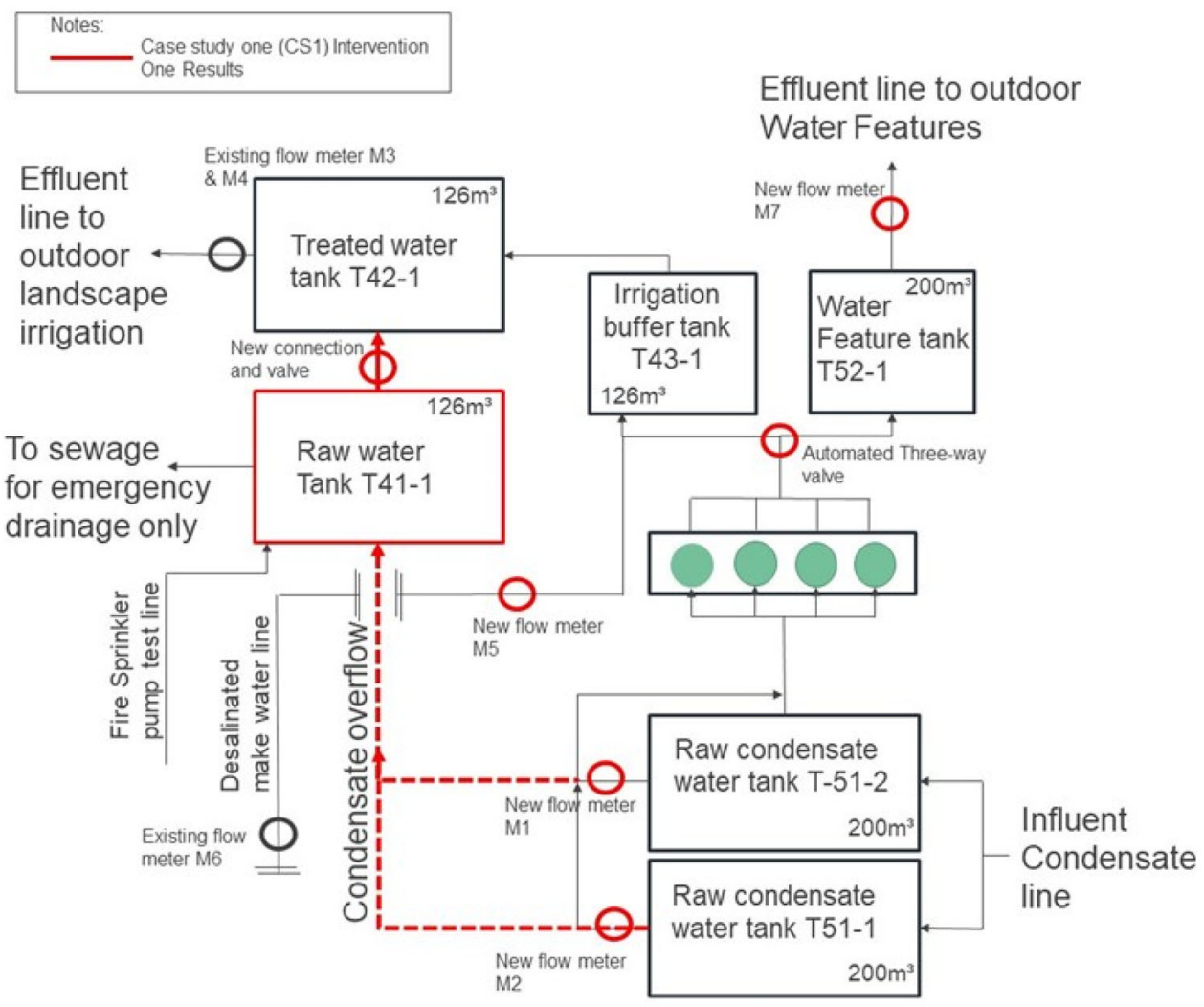

Fig. 9 CS1 Intervention One non-potable water system enhancement results

\subsubsection{Non-potable water storage}

The analysis of the water data collection from the EMCS 2017 records led the authors to find that the size restriction of the water collection tanks prevented $100 \%$ of the nonpotable water to be reused for LI and WF. This point is discussed in Sect. 3.1. For instance, in May 2017, 15,823 
$\mathrm{m}^{3}$ of condensate water was generated. The LI consumed $14,909 \mathrm{~m}^{3}$ of combined desalinated water and condensate water, and the WF used $1362 \mathrm{~m}^{3}$. Thus, the condensate water deficit was $478 \mathrm{~m}^{3}$. But the water system used 5957 $\mathrm{m}^{3}$ of desalinated makeup water, which means $5509 \mathrm{~m}^{3}$ excess desalinated water was used.

From the evidence collected and discussed in Sect. 3.1, the water wastage may have been caused by two problems: (a) water storage tank capacity or (b) non-potable water supply and timing.

The first point was addressed by the hydraulic review and rectified during the enhancement of the nonpotable water system (CS1 Intervention One), which involved connecting the tanks T41-1 and T42-1 (Fig. 9) to help minimize condensate water loss-evidenced by the increased level of condensate water use in 2017 compared to 2016. If the MFCS water tank size is assessed using the evaluation method recommended by Asano et al. (2007), it can be observed that the water tanks' capacity was sufficient in January 2018, after CS1 Intervention One was implemented. The Asano et al. (2007) method recommends allowing $25-50 \%$ of the maximum daily flow (demand) tributary to the reservoir. In the case of the MFCS, $402 \mathrm{~m}^{3}$ and $475 \mathrm{~m}^{3}$ per day were the peak flows for the WF and LI demand, respectively, in 2017. This means that the LI required a storage capacity of $119-237.5 \mathrm{~m}^{3}$. Connecting T42-1 and T42-2 provided a storage capacity of $252 \mathrm{~m}^{3}$ $\left(126 \mathrm{~m}^{3} \times 2\right)$, which is sufficient. For the WF water tanks, the recommended capacity is $100-200 \mathrm{~m}^{3}$ according to the Asano et al. (2007) method, which is also met by the existing tank capacity $\left(200 \mathrm{~m}^{3}\right)$.
The second point poses a problem because there is a lack of storage for excess condensate water, specifically in summer. This is evidenced by the 12 months water consumption records from 2017. The excess condensate water, totalling $73,767 \mathrm{~m}^{3}$, was drained to sewage. To store this water for future use, a large underground reservoir would be needed, a recommendation for future research. Part of this problem is a supply/demand imbalance between the time the condensate water is generated and the time at which water is needed to satisfy LI need, which can only be addressed by long-term storage (Asano et al. 2007). For instance, and as evidenced in Fig. 10, on December 4, 2017, the outdoor water demand was approximately 1000 $\mathrm{m}^{3}$, but only $500 \mathrm{~m}^{3}$ of condensate water was generated. There were four peaks of high-water demand during a period in which only small quantities of condensate were generated per day. When water demand is not aligned with the daily water supply, desalinated makeup water is used, which creates condensate water wastage. If a secondary $15,140 \mathrm{~m}^{3}$ (condensate water deficit quantity in 2017) 3 m-deep water reservoir capacity (Lo and Gould 2015) was available to store excess condensate water from peak times (summer), water storage tanks T41-1 and T-41-2 could pump extra non-potable water from the reservoir to meet the deficit. However, this solution requires more power $\left(0.30-0.50 \mathrm{~kW} / 1000 \mathrm{~m}^{3}\right)$ to recirculate the water of the reservoir to provide oxygen and eliminate destratification (Asano et al. 2007). The addition of chlorine may also be needed, to maintain a high free chlorine residual in the range $0.7-2.5 \mathrm{mg} / \mathrm{l}$ (ibid).

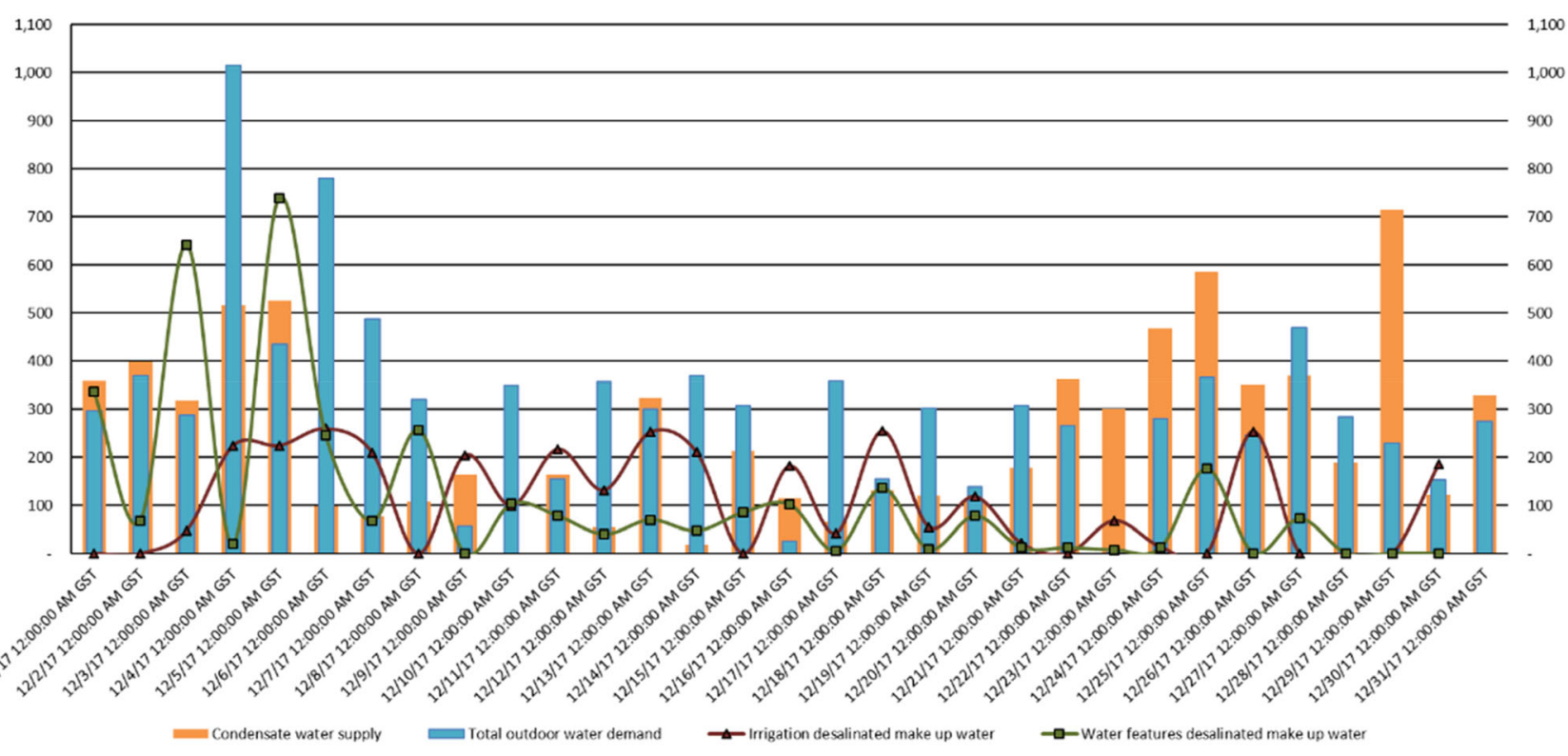

Fig. 10 Daily water used and supplied (EMCS December 2017 records) 


\subsection{Case study one calculation three (CS1 Calc3) results: WF demand}

Seguela et al. (2017c) established the energy consumption required to operate a combined $3289 \mathrm{~m}^{3}$ WF capacity based on $1587 \mathrm{~m}^{3}$ consumption average per month (CS1 calculation three (Water Features' Demand)) or $52 \mathrm{~m}^{3}$ per day-almost twice the $28 \mathrm{~m}^{3}$ per day original estimation by the consultants (Cardno 2014). Yet, the MFCS 2017 EMCS records show an average of $122 \mathrm{~m}^{3}$ per day, or $80 \%$ more than the CS1 calculation three and $60 \%$ more than Cardno's (2014) estimate. The total evaporation loss was estimated at $7216.68 \mathrm{~m}^{3} /$ year. In comparison, the UPC (2010a) provides $2.2 \mathrm{~m}^{3}$ per m$/$ year as an estimate, which is 3289 $\mathrm{m}^{2} \times 2.2 \mathrm{~m}^{3}$ per $\mathrm{m}^{2}=7235.80 \mathrm{~m}^{3} /$ year. That is a marginal difference of $0.26 \%$ against Seguela et al.'s (2017c) calculation. This provides evidence that the evaporation loss estimate is correct. The drain and refill periods must have been higher in 2017 than the estimate for maintenance and repair reasons.

\section{Discussion}

CS1 Intervention One (2017 Water Balance and NonPotable Water System Enhancement) included analysis of MFCS outdoor water consumption for 12 months (February 2017-January 2018), installation of additional water subflow meters and enhancement of the treated nonpotable water system. The latter two followed the hydraulic review recommendations of the author and were implemented by the third-party building engineer, in September 2018.

Fig. 11 CS1 Intervention One water balance analysis (2017)
CS1 Calculation three (Water Features' Water Demand Estimate) was conducted in July 2017, with results indicating WF water consumption in 2017 exceeded the calculated estimate by $80 \%$ due to maintenance and repair.

\subsection{CS1 water resources assessment outcome}

As discussed in Sect. 3.1, because there were no flow meters installed at the exit of the WF tank in 2016, it is not possible to make a comparison of the total water consumed outdoor in 2016 and 2017. However, 2016 data for LI condensate and desalinated makeup water consumption are available. Thus, the main observations on the water balance between 2016 (12 months) and February 2017-January 2018 (12 months) are as follows.

Observation One Referring to Fig. 2 (CS1 PP1 2016 and CS1 Intervention One), consumption of condensate water for LI decreased by $8 \%$ from $2016\left(91,564 \mathrm{~m}^{3}\right)$ to 2017 $\left(83,960 \mathrm{~m}^{3}\right)$ and consumption of desalinated makeup water decreased by $37 \%$. Total LI consumption of the combined AHU A/C condensate water and desalinated makeup water decreased by $18 \%$ from 2016 to 2017.

Observation Two Referring to Fig. 2 (CS1 PP1 2016, and CS1 Intervention One), in 2017, the MFCS generated $179,700 \mathrm{~m}^{3}$ of condensate water and consumed $161,762 \mathrm{~m}^{3}$ of water for WF and LI combined, of which 107,805 $\mathrm{m}^{3}$ was condensate water. This means no water deficit should have occurred because there was $17,938 \mathrm{~m}^{3}$ excess condensate water. However, the facility still used $53,957 \mathrm{~m}^{3}$ of desalinated makeup water.

Figure 11 provides a breakdown of total outdoor water consumption for 2017, against the available condensate water as recorded by the EMCS. It also includes the water consumed by the LI as excess water and the LI demand

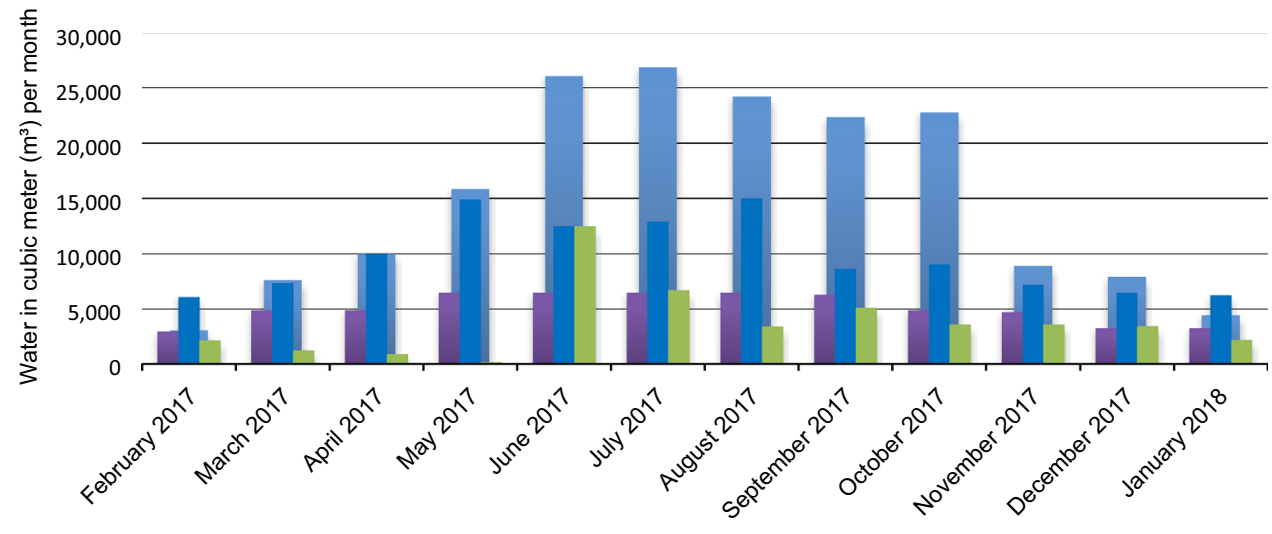

Months of the Year February 2017- January 2018

Total condensate water supply 2017(EMCS)

- Irrigation demand after soil improvement (as programed at the irrigation controller) Seguela et al (2017b)

Total landscape irrigation consumption 2017 (EMCS) M3 \& M4

Total water features consumption (EMCS) M7 
Fig. 12 CS1 Intervention One water balance: WF consumption based on 2017 EMCS records against CS1 Calc3 results

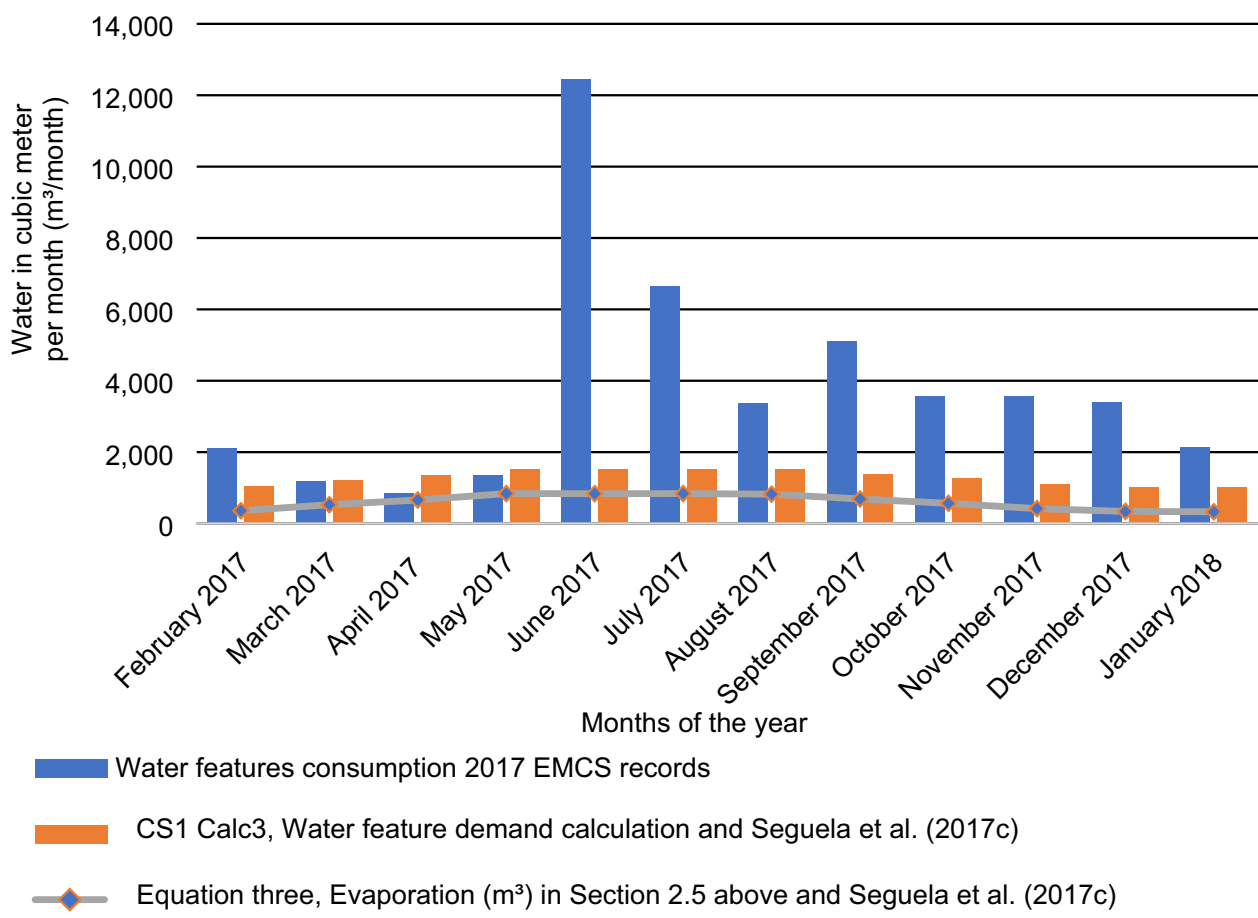

against the irrigation rate calculation based on the Soil Enhancement and Valve Flow Audit Implementation in Seguela et al. (2017b) and Seguela (2018). The MFCS exceeded the landscape water requirement by a minimum of $27 \%$ (September 2017) and a maximum of $57 \%$ (May and August 2017). This may explain why the condensate water deficit persisted for 7 months of the year in 2017. WF consumption also exceeded the calculated demand (Seguela et al. 2017c) except for November and December 2017 , as discussed further in this section.

Figure 12 provides details of total WF water consumption in 2017. 80\% more water was used than the demand calculated by Seguela et al. (2017c). The EMCS recorded $45,795 \mathrm{~m}^{3}$ (ave. $125 \mathrm{~m}^{3}$ per day) of water used solely for operation of the WF, while the calculations produce an estimated requirement for $15,590 \mathrm{~m}^{3}$ (ave. $42.7 \mathrm{~m}^{3}$ per day). The O\&M team stated that there was a waterproofing issue with the main WF, which had to be drained and filled several times during the summer. This would explain the peak use of desalinated water in June, July and September 2017, the period over which the repairs occurred. Additionally, in March 2017, condensate water was not collected for reuse but drained to sewage due to maintenance activity. In June, July and September 2017, the raw condensate water tanks were drained, cleaned and disinfected. These tanks are installed on concrete and have two isolated compartments with no inter-connection. When one tank is cleaned the other functions normally, but the water is drained to the sewage drainage during the cleaning process. The quantity of condensate water drained is not known.

Considering Seguela et al.'s (2017c) calculation results, the total capacity of the WF, the quarterly maintenance drain, down and refill, the backwash and the high level of evaporation representing $56.5 \%$ average of the water used (see Fig. 12), the WF should not consume more than 1299 $\mathrm{m}^{3}$ per month as detailed in Table 4 .

Table 4 CS1 Intervention One WF consumption results based on CS1 Calc3

\begin{tabular}{|c|c|c|c|c|}
\hline WF characteristics & Average in Summer & Average in Winter & Average in Spring & Average in Autumn \\
\hline Total capacity $\left(\mathrm{m}^{3}\right)$ & 1352 & & & \\
\hline Drain and refill $\left(\mathrm{m}^{3}\right)$ & 450 & & & \\
\hline Backwash $\left(\mathrm{m}^{3}\right)$ & 248 & & & \\
\hline Evaporation $\left(\mathrm{m}^{3}\right)$ (IWMI, 2018) & 804.66 & 342.11 & 592.12 & 491.19 \\
\hline Precipitation (millimeter (mm) per month) (NCM 2017) & 0.00 & 9.70 & 7.05 & 1.25 \\
\hline Total in $\left(\mathrm{m}^{3}\right)$ per month & 1502.61 & 1065.94 & 1289.60 & 1189.68 \\
\hline
\end{tabular}


Fig. 13 CS1 Intervention One water balance: LI consumption based on 2017 EMCS records against CS1 Calc1 and intervention two results

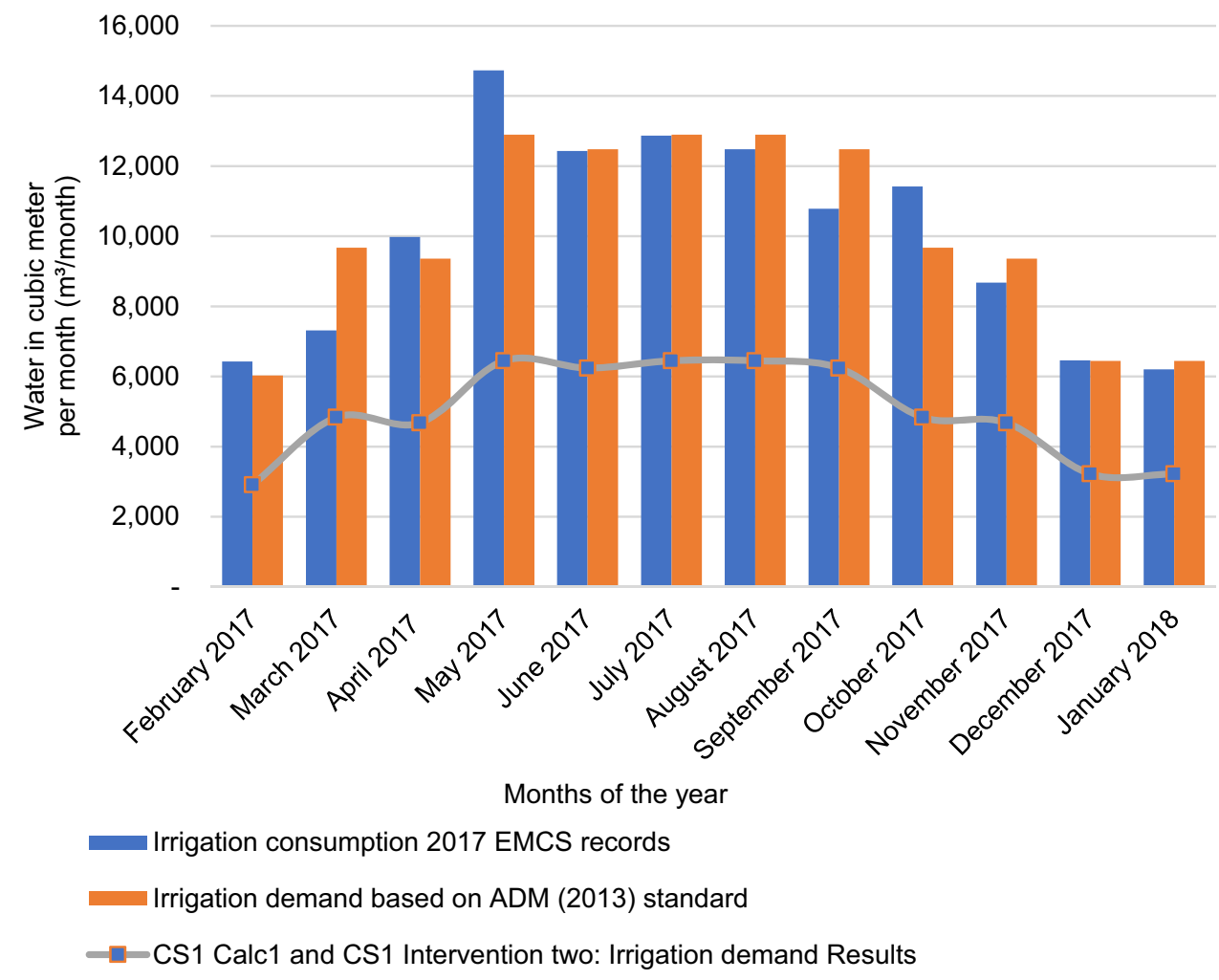

Table 5 CS1 Intervention One LI and WF 7 months consumption summary

\begin{tabular}{|c|c|c|c|c|c|c|c|}
\hline $\begin{array}{l}\text { Months of the year incurring a water } \\
\text { deficit }\end{array}$ & $\begin{array}{l}\text { February } \\
2017\end{array}$ & $\begin{array}{l}\text { March } \\
2017\end{array}$ & $\begin{array}{l}\text { April } \\
2017\end{array}$ & $\begin{array}{l}\text { May } \\
2017\end{array}$ & $\begin{array}{l}\text { November } \\
2017\end{array}$ & $\begin{array}{l}\text { December } \\
2017\end{array}$ & $\begin{array}{l}\text { January } \\
2018\end{array}$ \\
\hline \multicolumn{8}{|l|}{ LI consumption (in $\mathrm{m}^{3}$ per day) } \\
\hline $\begin{array}{l}\text { Based on } 2017 \text { EMCS consumption } \\
\text { records }\end{array}$ & 216.30 & 236.00 & 332.50 & 480.93 & 238.00 & 208.40 & 202.19 \\
\hline Based on CS1 Calculation one results & 104.00 & 156.00 & 156.00 & 208.00 & 156.00 & 104.00 & 208.00 \\
\hline \multicolumn{8}{|l|}{ WF consumption (in $\mathrm{m}^{3}$ per day) } \\
\hline $\begin{array}{l}\text { Based on } 2017 \text { EMCS consumption } \\
\text { records }\end{array}$ & 118.80 & 109.60 & 75.20 & 43.93 & 38.70 & 25.80 & 69.50 \\
\hline Based on CS1 calculation three results & 37.70 & 39.47 & 45.18 & 49.57 & 37.18 & 33.43 & 33.11 \\
\hline
\end{tabular}

Figure 12 and Table 4 provide evidence that in March 2017, $38 \mathrm{~m}^{3}$ water per day was consumed for the WF, which is very close to Seguela et al.'s (2017c) calculated estimate of $42.7 \mathrm{~m}^{3}$ per day.

For LI, a similar scenario occurred. As shown in Fig. 13, the water consumption did not follow the pattern of the actual LI water demand based on Abu Dhabi Municipality (ADM 2013) standard irrigation rates before soil amendment (Seguela et al. 2017b; Seguela 2018). In March, April and September 2017, more water was consumed than the amount required by the standard (ADM 2013). In addition, from July 2017, at which time the soil amendment dictated the irrigation rate based on CS1 Calc 1 (Seguela 2018)-or
$50 \%$ less water than the ADM (2013) standard-the usage did not reflect this new prediction of water demand. Thus, from July 2017 to January 2018, 35,100 $\mathrm{m}^{3}$ of water should have been used for LI when in fact $65,274 \mathrm{~m}^{3}$ was consumed- $-60 \%$ more than predicted.

The reason for the excessive water consumption is either (a) the landscape contractor did not reprogram the irrigation controller after the 2017 valve flow audit to align with the soil enhancement irrigation rate (Seguela et al. 2017b), or (b) there is leakage in the LI water pipework. LI consumption has been established at $57,096 \mathrm{~m}^{3}$ per year as per the LI demand detailed in Seguela et al. (2017b); Seguela (2018). As of April 2018, the LI and the WF incurred a 
Fig. 14 CS1 Intervention One water balance: LI and WF water consumption against available condensate water supply based on 2017 EMCS records

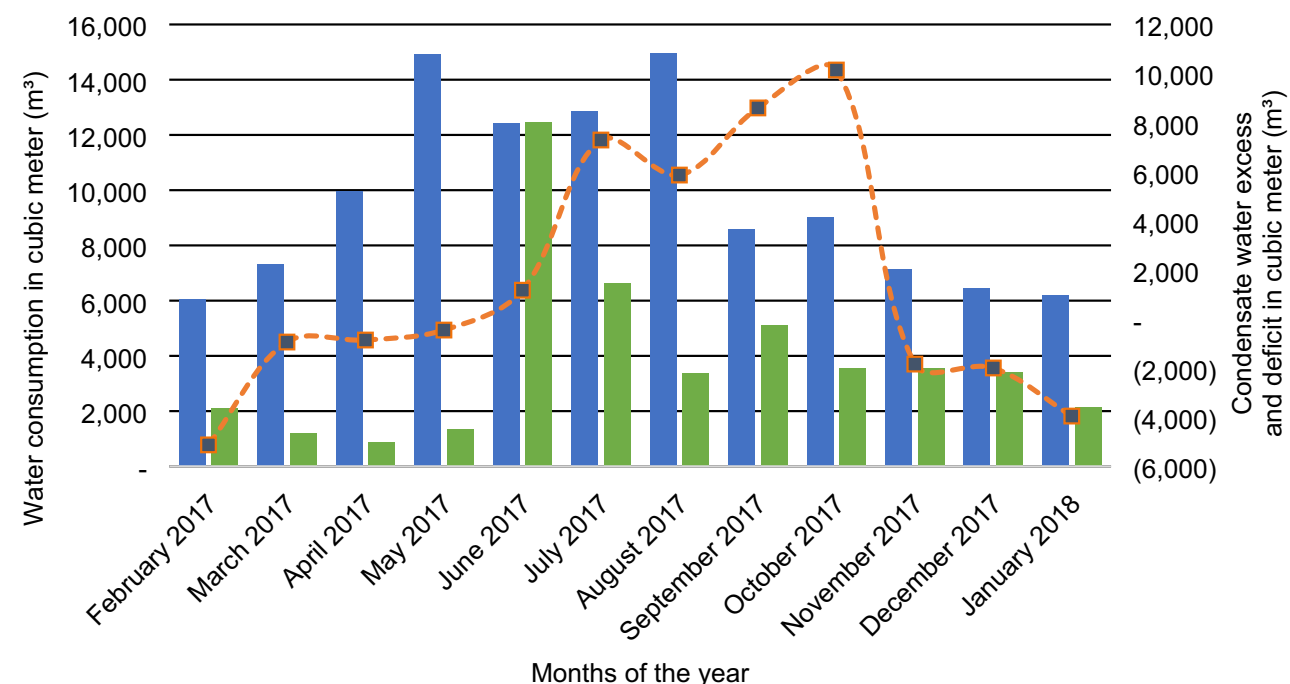

CS1 Intervention One: Total landscape irrigation consumption 2017 (EMCS) M3 \& M4

CS1 Intervention One: Total water features consumption (EMCS) M7

- CS1 Intervention One Results: Total AHU A/C condensate water deficit/excess based on 2017 EMCS records

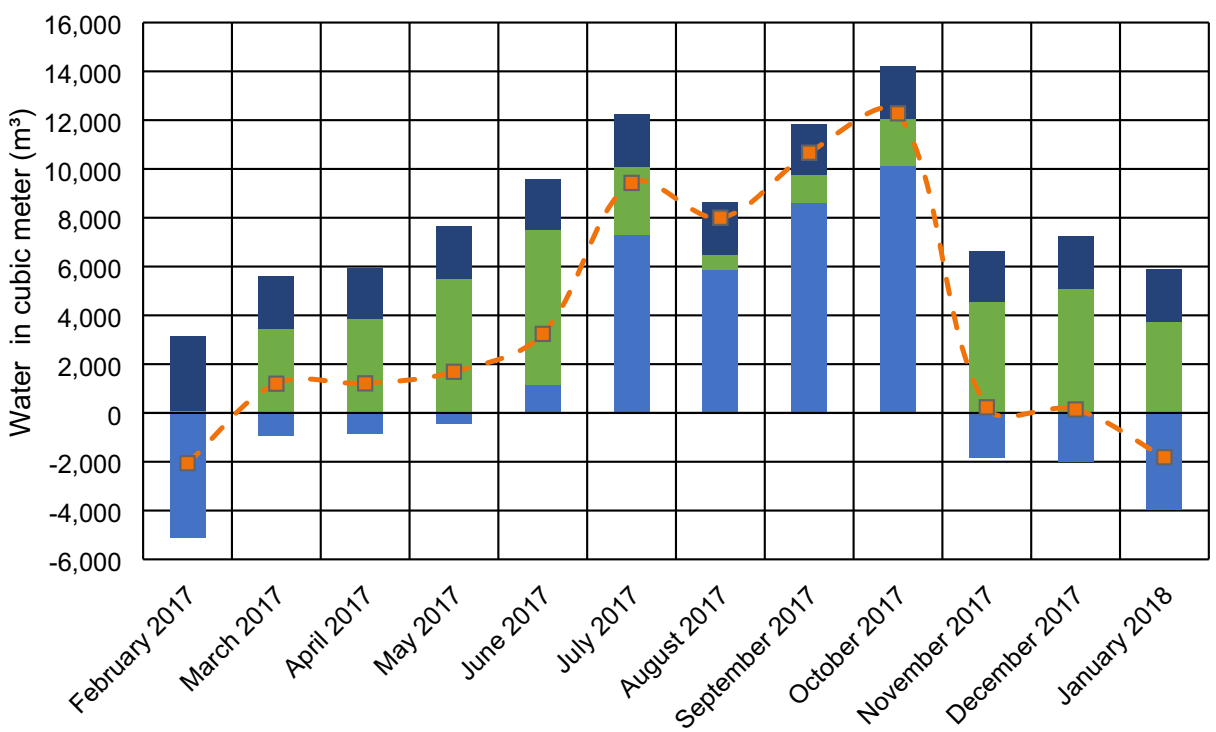

Months of the year

Fig. 15 CS1 Intervention One and CS1 Calc2 results: condensate water deficit and excess against desalinated makeup water based on 2017 EMCS records 
Table 6 CS1 Intervention One 2017 outdoor water wastage summary

\begin{tabular}{lll}
\hline Types of water wastage & Quantities in $\mathrm{m}^{3}$ per year & Reasons \\
\hline Desalinated water use excess & $42,768.00$ & Outdoor water systems unautomated \\
Outdoor valve flow audit results & 1567.94 & Building outdoor water systems audit and verification \\
Unused condensate water by lack of storage & $73,767.00$ & $\begin{array}{c}\text { Outdoor water systems unautomated and lack of tank } \\
\text { storage }\end{array}$ \\
Over irrigation (from July to January 2018) & $30,174.00$ & Irrigation controller and EMCS incompatibility \\
Excess water used for WF drain and fill during repair & $29,012.00$ & Lack of care from the operation and maintenance team \\
Total & $177,288.94$ & \\
\hline
\end{tabular}

condensate water deficit for 7 months of the year as detailed in Table 5. This data analysis provides evidence that consumption is above the required level.

Figure 14 provides evidence of the condensate water deficit for 2017 based on the 2017 EMCS records. From November to May, there is not enough condensate water $\left(-11,189 \mathrm{~m}^{3}\right)$ to supply the 2017 excess consumption of LI and WF.

In addition to the shortfall in condensate water, the nonpotable water system used more makeup water than predicted. Figure 15 provides the 2017 EMCS record of the excess desalinated makeup water used for both LI and WF in addition to the supplied condensate water. $53,957 \mathrm{~m}^{3}$ of desalinated makeup water was used when only $11,189 \mathrm{~m}^{3}$ was needed to supply the deficit, which represents $117 \%$ water wastage.

Considering total water wastage in 2017 against the water deficit $\left(11,189 \mathrm{~m}^{3}\right)$ recorded by the EMCS that year, Table 6 provides evidence that a winter water deficit only occurs in February, as opposed to the 6 months and 7
Fig. 16 CS1 Intervention One water balance based on CS1 Calc 1 and CS1 Calc3 against available condensate water supply

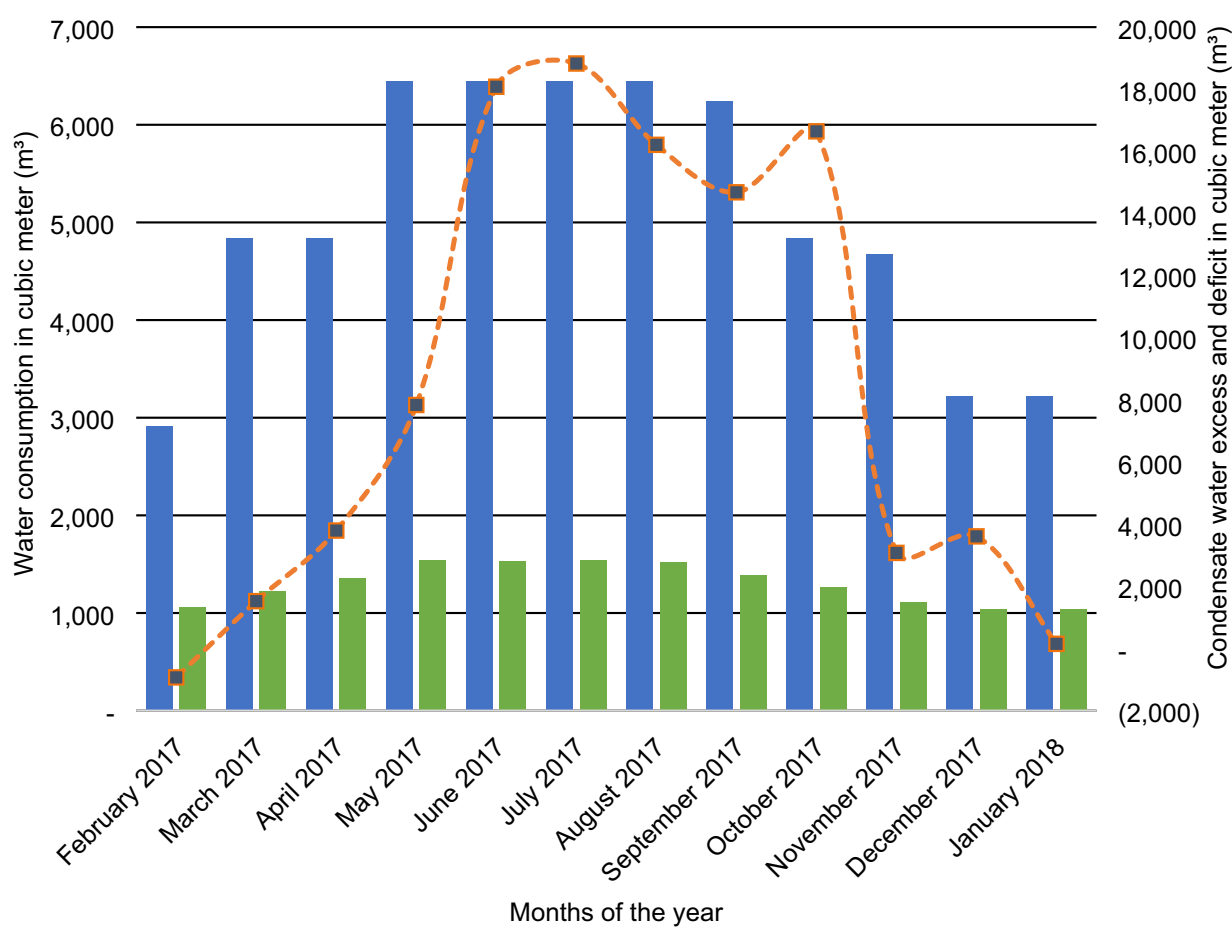

Irrigation demand after soil improvement as a result of CS1 Intervention Two and CS1 Calc1

Water features demand estimate as a result of CS1 Calc3

- Total condensate water excess/deficit as a result of CS1 Intervention One, CS1 Intervention Two, CS1 Calc1 and CS1 Calc3 
months anticipated deficit in 2016 and 2017, respectively, because water has been wasted.

The water wastage illustrated in Table 6 mainly related to field testing and verification, water tank storage challenges, a lack of experience in the O\&M team, LI and energy management and a lack of direction from the Abu Dhabi Standards and policies.

The irrigation rate calculation in Seguela et al. (2017b) and Seguela (2018) has been revised to below $50 \%$ of the ADM (2013) standard requirements since the soil was amended in 2017 (ibid.). This is reflected by the updated irrigation controller A and B schedule issued by the landscape contractor in September 2017. Yet the 2017 EMCS records do not show irrigation consumption in line with the revised schedules or the expected savings (ibid.).

It is evident, from the above analysis, that LI and WF wasted $11,189 \mathrm{~m}^{3}$ of (both condensate and makeup desalinated) water.

\subsection{MFCS alternative response}

Considering the findings above regarding condensate water and desalinated makeup water quantities, it is evident that the MFCS is using too much water and that the deficit in condensate water should only be minor. Figure 16 provides the total outdoor water demand consumption against the available condensate water supplied in 2017 (EMCS records). This water demand is based on CS1 Calc 3 (WF demand calculations) and Seguela et al. (2017c), and the irrigation rate implementation after soil amendment (Seguela et al. 2017b; Seguela 2018). This model shows a surplus of condensate water all year around except for February, which scored a $30.5 \%$ deficit. In addition, the months of November 2017, December 2017 and March 2017 show the lowest level of available condensate, whereas the months of June to October show the highest levels.

Finally, the numerical data helps, firstly, to establish end-user (LI and WF) consumption patterns and, secondly, to identify water loss for each water type (potable and nonpotable) at specific time of use. This water analysis provides evidence that non-potable water is in excess, not deficit, for most of the year. This point is developed further below.

\subsection{Contribution to change in practice: non- potable water systems design and operation}

CS1 Intervention One (2017 Water Balance and NonPotable Water System Enhancement) was initiated by the author in 2017 following the 2016 hydraulic review to:
- Monitor non-potable and makeup water quantities used for WF and LI by installing new subflow meters at the exit of the $\mathrm{A} / \mathrm{C}$ condensate water tanks and the WF tank, and the desalinated makeup water line.

- Produce savings in energy and reduce water loss and maintenance costs by integrating mechanical data from the irrigation pump controller system to the EMCS, by verifying the WF pumps' variable frequency drive (VFD) fault and run status, and by verifying the valve flow of the irrigation system (Seguela 2018).

- Automate the water system to ensure non-potable water is used as the main source of water supply and thus decrease desalinated water use.

- Ensure a higher level of non-potable water quality for reuse to minimize excess chemical use (i.e., ozone, chlorine) and make water treatment "fit for purpose" by retro-commissioning the tertiary treatment system (ozone chlorine) for WF and by installing a new tertiary treatment system (UV) for LI (Seguela 2018).

- Minimize non-potable water loss by increasing the A/C condensate water storage capacity for when it is most needed (winter). The water storage capacity can be calculated by a mechanical engineer to estimate inflow and outflow provided the landscape contractor has estimated the LI demand.

- Verify the design intent is in line with the "As-Built" post-opening through to retro-commissioning.

\subsection{Water resources implications and risks summary}

Table 7 provides a model summarizing the method employed to identify non-potable water resources implications and risks aimed at the audience target (landscape contractors, facility managers and building owners). More specifically, it provides the outcome of the water wastage analysis developed above and the implications for overall O\&M savings on the cost of purchasing water and the GHG impact associated with the production of desalinated water at a rate of 15.40 kilowatt hour $(\mathrm{kWh})$ per $\mathrm{m}^{3}$ (MOEW 2010).

These recommendations apply to the design and construction; building operations, maintenance and facilities management; and environmental management sectors seeking to improve outdoor water conservation programs to save on cost and minimize environmental impact.

A comparison has been established for the combined total water consumed between the 2 years (2016 and 2017) for irrigation. This demonstrates the need to install flow meters and subflow meters so that consumption can be closely monitored and promptly rectified to avoid wastage. As discussed above, despite WF repairs at the MFCS, the 
Table 7 Water resources reuse and risks summary

\begin{tabular}{llc}
\hline $\begin{array}{l}\text { Water resources and associated } \\
\text { issues }\end{array}$ & Implications for the audience target & Risks \\
\hline $\begin{array}{l}\text { A/C condensate water } \\
\text { Non-potable system }\end{array}$ & $\begin{array}{l}\text { Monitor quantities for reuse by flow metering } \\
\text { Provide sufficient long-time storage at design stage preferably to minimize cost }\end{array}$ & $\begin{array}{c}\text { Water wastage } \\
\text { water wastage } \\
\text { Water reports }\end{array}$ \\
$\begin{array}{l}\text { Water efficiency for non- } \\
\text { potable water systems }\end{array}$ & Schedule water report during outside operating hours & Water leakage \\
& Verify valve flow & Water wastage \\
& Check pump pressure set point & \\
& Install WF and LI compatible water monitoring systems (LI sensors, flow meters, \\
& pumps, treatment dosage system) & \\
\hline
\end{tabular}

presence of outdoor leakage is highly probable given the observed irregularities in LI water consumption. Accordingly, the EMCS should record water consumption outside the irrigation time frame (12:05 am to 5:55 am) so that abnormal water consumption can be detected (Farley and Trow 2003; Hamilton and McKenzie 2014). If abnormalities are observed an acoustic leakage detection, audit should be conducted at the MFCS by a specialist third party (AWWA 2016).

\section{Conclusion}

The case study has shown that water wastage is mainly related to field testing and verification, non-potable water tank storage challenges and LI and WF water demand management by the O\&M team. Considering the findings regarding condensate water and desalinated makeup water quantities, it is evident that the MFCS is using an excessive quantity of water and that a deficit in condensate water should only be occurring 2 months per year, as opposed to the current seven months. The LI intervention has not been fully implemented, and the WF were being repaired in 2018; for these reasons, the MFCS is over-consuming water, and thus, the $\mathrm{AHU} \mathrm{A} / \mathrm{C}$ condensate water deficit persists. This case study demonstrates the benefits of using onsite treated non-potable water to eliminate the use of desalinated water and decrease water wastage by (a) controlling water demand; (b) building sufficient nonpotable water storage tanks capacity and including an automated water system; (c) providing sub-metering for non-potable water usage; and (d) ensuring the EMCS is compatible with the irrigation controller system. Because A/C condensate water supplies are seasonal, water storage should be calculated to allow for additional storage in summer, if possible, so that the water can be reused in winter. In addition, water storage should be calculated in collaboration with the landscape designer to ensure storage tanks will be large enough to sustain the daily water demand and water reservoir when the generation of condensate water is large, to avoid water wastage through dumping. Outdoor water systems should undergo ongoing verification including water leakage audit, yearly flow meters calibration, pressure set point verification and pump efficiency audit. Finally, the EMCS should be programmed to deliver reports outside the normal operating hours in addition to daily water consumption reports to detect water use abnormalities.

The unique contribution of this research is the demonstration that outdoor water supply and demand management have a large role to play in (a) helping minimize water wastage, a direct contributor to GHG emissions, and (b) alleviating water stress in AD. It has been demonstrated that water data analysis helps identify water consumption patterns, avoid water wastage and reduce operating costs when using different types of water for various outdoor end uses. The authors encourage HAAD, DMAT, UPC and EAD to adopt a potable water reduction protocol for $\mathrm{LI}$ and WF in healthcare estates in $\mathrm{AD}$ to reduce potable water use and wastage and the associated energy use and carbon emissions from desalination, and to also help the city meets its 2030 goal of reducing GHG emissions by $22 \%$.

Acknowledgements Very special thanks go to the Medical Facility (MF) for their support, with a special mention to the Chief Academic Officer and Chief Cardiovascular Medicine in the Heart and Vascular Institute at the MF; the Senior Director hospital operations at the MF; and members of the building owner's team. The main author is also grateful to the MF staff and contractors including the building services specialist, the Mechanical Electrical Plumbing management team and the landscape contractor's management team.

\section{Compliance with ethical standards}

Conflict of interest On behalf of all authors, the corresponding author states that there is no conflict of interest. 
Open Access This article is licensed under a Creative Commons Attribution 4.0 International License, which permits use, sharing, adaptation, distribution and reproduction in any medium or format, as long as you give appropriate credit to the original author(s) and the source, provide a link to the Creative Commons licence, and indicate if changes were made. The images or other third party material in this article are included in the article's Creative Commons licence, unless indicated otherwise in a credit line to the material. If material is not included in the article's Creative Commons licence and your intended use is not permitted by statutory regulation or exceeds the permitted use, you will need to obtain permission directly from the copyright holder. To view a copy of this licence, visit http://creativecommons. org/licenses/by/4.0/.

\section{References}

Abu Dhabi Distribution Company (2017) Water and energy tariffs 2017. https://www.addc.ae/en-US/residential/Documents/02-Eng lish.pdf. Accessed 10 Jan 2017

Abu Dhabi Municipality (2013) Irrigation systems operation and maintenance. Parks and Recreation Facilities Division: AD, 2C Section 02800

American Society of Heating, Refrigerating and Air-Conditioning Engineers (2000) Guideline 12-2000-Minimizing the risk of legionellosis associated with building water systems. https:// www.ashrae.org/resources-publications/bookstore/ansi-ashraestandard-188-2015-legionellosis-risk-management-for-buildingwater-systems. Accessed 6 Feb 2017

American Water Works Association (2016) Manual of water supply practices: water audits and loss control programs, 4th edn. AWWA, Denver

Asano T, Burton FL, Leverenz HL, Tsuchihashi R, Tchobanoglous G (2007) Water reuse: issues, technologies, and applications. McGrawHill, New York

Cardno (2014). Greywater/condensate water risk assessment Report. Unpublished manuscript. MFCS, Abu Dhabi

Creswell JW, Plano Clark VL (2011) Designing and conducting mixed methods research, 2nd edn. Sage, London

Department of Municipal Affairs and Transport (2013) Abu Dhabi International Building Code: Plumbing Systems (Chapter 29). DMAT, Abu Dhabi, p 501

Environment Agency- Abu Dhabi (2009) Uniform Plumbing Code of Abu Dhabi. https://www.ead.ae/Documents/researchers/Uni form\%20plumbing $\% 20$ code $\% 20$ of $\% 20$ abu $\% 20$ dhabi $\% 20$ emi rate.pdf. Accessed 30 Jan 2014

Environment Agency- Abu Dhabi (2012) Greenhouse Gas Inventory for Abu Dhabi. https://www.ead.ae/Documents/PDF-Files/ADGreenhouse-gas-inventory-Eng.pdf. Accessed 30 Jan 2014

Environment Agency-Abu Dhabi (2014) The Water Resources Management Strategy for the Emirates of Abu Dhabi 2014-2018. https://www.ead.ae/Documents/PDF-Files/Execu tive-Summary-of-The-Water-Resources-Management-Strategyfor-the-Emirate-of-Abu-Dhabi-2014-2018-Eng.pdf. Accessed 30 Jan 2014

Environment Agency-AD (2017) Abu Dhabi State of Environment Report 2017. https://www.ead.ae/Publications/Abu\%20Dhabi\% 20State $\% 20$ of\%20Environment\%20Report\%202017/EAD-fullreport.pdf. Accessed 28 March 2018

ESD (2016) Non-Potable Water Use Report. Unpublished manuscript. MFCS, Abu Dhabi

Farley M, Trow S (2003) Losses in water distribution networks: a practitioners' guide to assessment. IWWA Publishing, London, Monitoring and Control
Fédération International de Natation (2018). FR 3 swimming pools for olympic games and world championships. http://www.fina. org/content/fr-3-swimming-pools-olympic-games-and-worldchampionships. Accessed 8 May 2018

Forrest N, Williams E (2010) Life cycle environmental implications of residential swimming pools. Environ Sci Technol 23(1):147-152

Gallion T, Harrison T, Hulverson R, Hristovski K (2014) Estimating water, energy and carbon footprints of residential swimming pools. In: Ahuja S (ed) Water reclamation and sustainability, 1st edn. Elsevier, San Diego, pp 343-359

Hamilton S, McKenzie R (2014) Water management and water loss. IWWA Publishing, London

Health Authority Abu Dhabi (2011) EHSMS Standard 12-Water Quality

HAAD. Health Authority Abu Dhabi (2012) EHS Regulatory Instrument Code of Practice EHS RI- COP 12- Prevention and Control of Legionnaires Disease. v2. OSHAD, Abu Dhabi. https://www.oshad.ae/. Accessed 15 Jan 2016

HERC. Healthcare Environmental Resource Center (2015) Facilities Management- Water Conservation. http://www.hercenter.org/ facilitiesandgrounds/waterconserve.cfm. Accessed on 5 July 2015

International Water Management Institute (2018) Online Climate Service Model. http://wcatlas.iwmi.org/results.asp. Accessed 20 Jan 2017

Jarrar A (2017) Utilization of treated sewage effluent for Landscape Irrigation in $\mathrm{Abu}$ Dhabi City. Presentation at the Future Landscape \& Public Realm Conference, Abu Dhabi, UAE, 6-7 Feb

Lo AG, Gould J (2015) Rainwater harvesting: global overview. In: Zhu Q, Gould J, Li Y, Ma X (eds) Rainwater harvesting for agriculture and water supply. Science Press, Beijing, pp 213-235

Magoon C, Villars KE, Evans J (2010) Water supply and treatment design in rural Belize: a participatory approach to engineering action research. Int J Service Learn Eng 1:1. https://doi.org/10. 24908/ijsle.v5i1.2232

Ministry of Environment and Water (2010) United Arab Emirates Water Conservation Strategy. http://extwprlegs1.fao.org/docs/ pdf/uae147095.pdf. Accessed 6 Feb 2017

Mitchell K (2009) From increasing supply to managing demand. In: Reisz T (ed) Al Manakh 2: Cont'd. Stichting, Archis, Amsterdam, pp 114-117

National Centre of Meteorology (2017) Climate Yearly Report of AD 2003-2016. http://www.ncm.ae/en/climate-reports-yearly. html?id=26. Accessed 6 Feb 2017

Pizzi NG (2010) Water treatment: principles and practices of water supply operations, 4th edn. American Water Works Association, Denver

Regulatory Supervision Bureau (RSB) (2010) Guide to recycled water and biosolids regulations 2010. Abu Dhabi. http://rsb.gov.ae/ assets/documents/264/regsrwb2010.pdf. Accessed 12 Sept 2012

Seguela G (2018) Implementation and evaluation of an outdoor water conservation strategy for hospital decarbonisation in an arid climate. Unpublished Professional Doctorate in Engineering Thesis, Cardiff Metropolitan University

Seguela G, Littlewood JR, Karani G (2017a) Onsite food waste processing as an opportunity to conserve water in a Medical Facility Case Study. Energy Procedia, Abu Dhabi. https://doi. org/10.1016/j.egypro.2017.03.217

Seguela G, Littlewood JR, Karani G (2017b) Eco-engineering strategies for soil restoration and water conservation: investigating the application of soil improvements in a semi-arid climate in a Medical Facility Case Study, AD. J Ecol Eng. https://doi.org/ 10.1016/j.ecoleng.2017.07.020 
Seguela G, Littlewood JR, Karani G (2017c) A study to assess nonpotable water sources for reducing energy consumption in a Medical Facility Case Study, Abu Dhabi. Energy Procedia 134:797-806. https://doi.org/10.1016/j.egypro.2017.09.532

Seguela G, Littlewood JR, Karani G (2020) A GHG metric methodology to assess onsite buildings non-potable water system for outdoor landscapeuse. J Appl Sci. https://doi.org/10.3390/ app10041339. Accessed 16 Feb 2020

Shahid SA, Abdelfattah MA, Othman Y, Kumar A, Taha FK, Kelleym JA, Wilson MA (2013) Innovative thinking for sustainable use of terrestrial resources in Abu Dhabi Emirate through scientific soil inventory and policy development. In: Shahid S et al (eds) Developments in soil classification, land use planning and policy implications. Springer, Dordrecht, pp 3-49

United States Environment Protection Agency Office of Water (2012) Guidelines for Water Reuse. https://watereuse.org/wp-content/ uploads/2015/04/epa-2012-guidelines-for-water-reuse.pdf. Accessed 03 Jan 2017
Urban Planning Council (2010a) Pearl Building Rating System: Design \& Construction. UPC, Abu Dhab. https://www.upc.gov. ae/en/publications/manuals-and-guidelines/public-realm-ratingsystem. Accessed 04 April 2018

Urban Planning Council (2010b) Abu Dhabi Public Realm Design Manual. UPC, Abu Dhabi. https://www.cip-icu.ca/pdf/2011HM-Urban-Design2(1).pdf. Accessed 04 April 2018

Veerapaneni S, Long B, Freeman S, Bond R (2007) Reducing energy consumption for seawater desalination. Journal of American Water Works Association 99(6):95-106

Wheeler F, Elam E (2015) Fundamentals of water efficiency. Association of Energy Engineers, Washington

World Bank (2012) In: Verner D (ed) Adaptation to a Changing Climate in the Arab Countries: A Case for Adaptation Governance and Leadership in Building Climate Resilience. World Bank, Washington DC http://dx.doi.org/10.1596/978-0-82139459-5. Accessed 10 September 2016

Yin RK (2014) Case study research: design and methods, 5th edn. Sage, London 